Technology Demonstration of Self-Healing Coatings for In-Place Management of LeadBased Paint Hazards

US Army Corps of Engineers $\odot$

Engineer Research and Development Center

L. D. Stephenson and Ashok Kumar

December 2003

Microcapsules

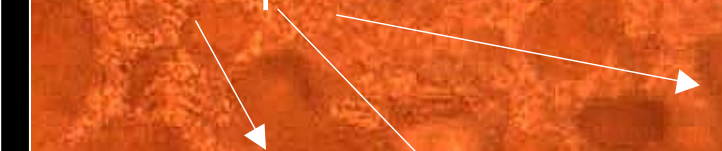





\section{Technology Demonstration of Self-Healing Coatings for In-Place Management of Lead-Based Paint Hazards}

L. D. Stephenson and Ashok Kumar

Construction Engineering Research Laboratory

PO Box 9005

Champaign, IL 61826-9005

Final Report

Approved for public release; distribution is unlimited.

Prepared for Headquarters, Department of the Army

Washington, DC 20310-0600

Under

Work Unit CF-M B101 
ABSTRACT: Microscopic capsules have been developed on the order of 50-150 microns in size. These microcapsules can contain a small quantity of liquid, and they will release their contents when broken. Microcapsules containing paint repair and lead dust suppression compounds can be mixed into commercially available latex coatings and used to overcoat existing lead-based paint (LBP) on older buildings. If such an overcoating is damaged, the microcapsules break open and release their self-repair compounds to forestall overcoat degradation and inhibit hazardous quantities of lead entering the environment.

The U.S. Army Engineer Research and Development Center, Construction Engineering Research Laboratory (ERDC/CERL) tested 'self-healing' coatings in the laboratory and demonstrated them on an aged wood building at the former Fort Ord, CA. In both the laboratory and field demonstration, when the self-healing coatings were applied over lead-based paint, intentionally damaged, and wipe-tested, significant reductions in lead dust were realized compared with the results of the same test procedure applied to LBP overcoated with standard latex paint.

DISCLAIMER: The contents of this report are not to be used for advertising, publication, or promotional purposes. Citation of trade names does not constitute an official endorsement or approval of the use of such commercial products. All product names and trademarks cited are the property of their respective owners. The findings of this report are not to be construed as an official Department of the Army position unless so designated by other authorized documents.

DESTROY THIS REPORT WHEN NO LONGER NEEDED. DO NOT RETURN IT TO THE ORIGINATOR. 


\section{Contents}

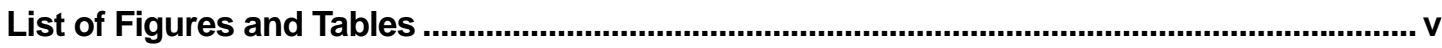

Conversion Factors .......................................................................................................... vii

Preface

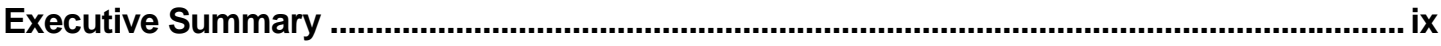

1 Introduction

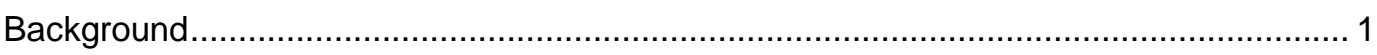

Objective

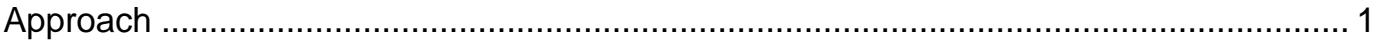

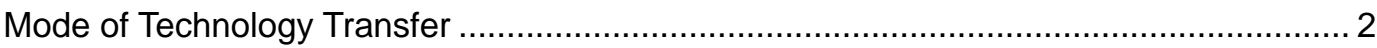

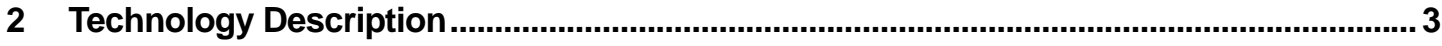

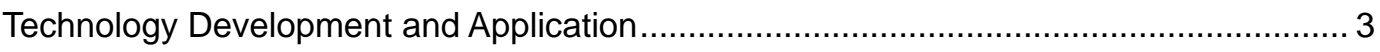

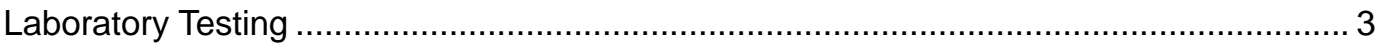

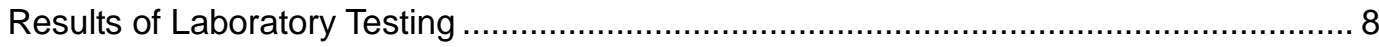

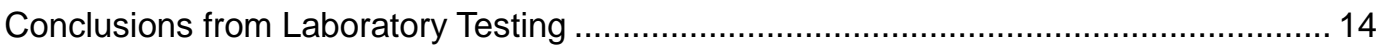

Advantages and Limitations of the Technology ...................................................... 14

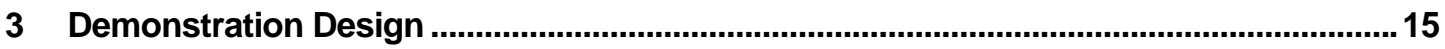

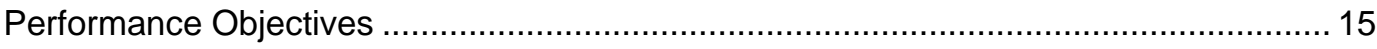

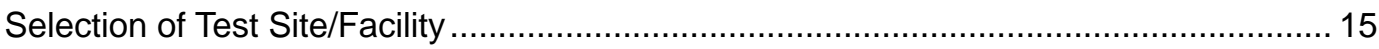

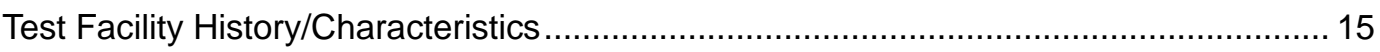

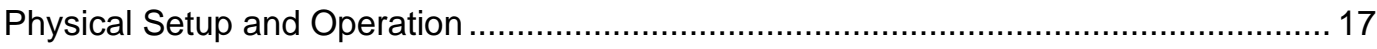

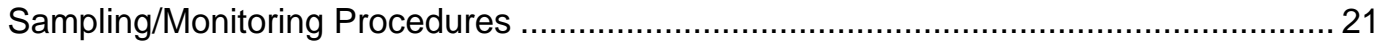

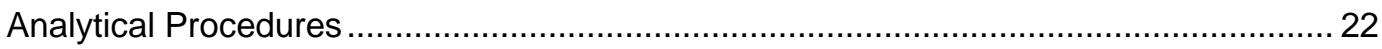

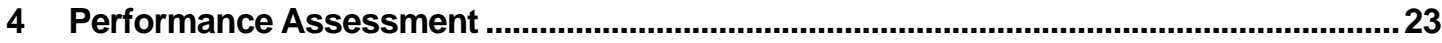

Performance Data

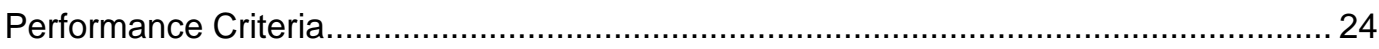

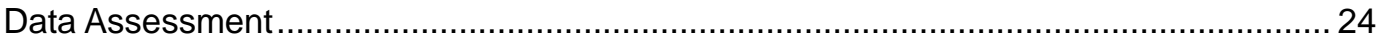

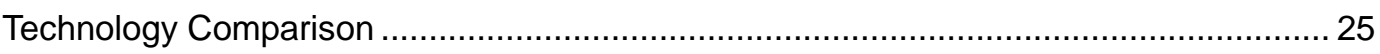

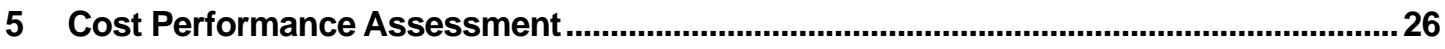

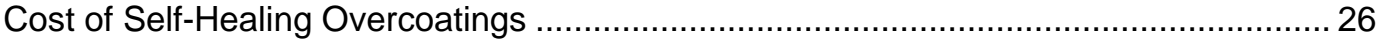

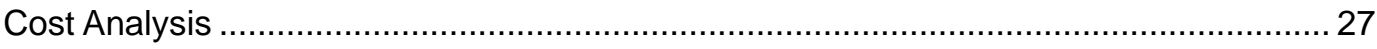

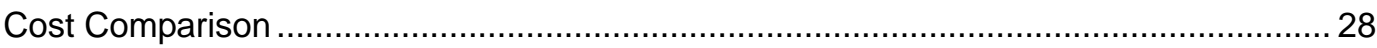

6 Summary 


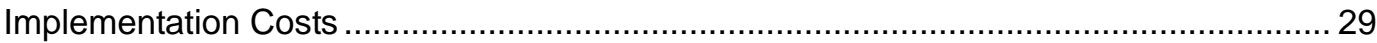

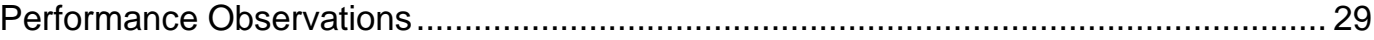

References

Points of Contact

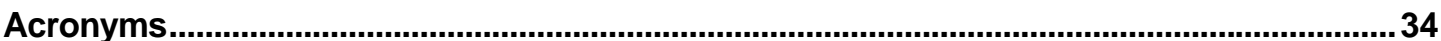

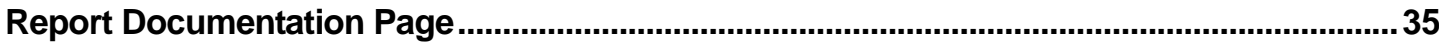




\section{List of Figures and Tables}

\section{Figures}

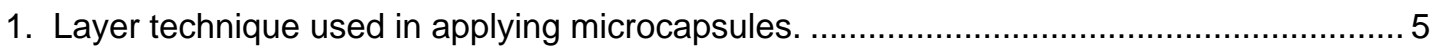

2. Optical micrograph of microcapsules within the self-healing overcoating for the LBP........5

3. Release of red dye from ruptured microcapsules illustrating self-healing mechanism.

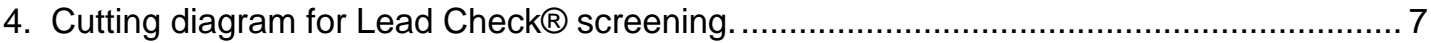

5. Comparison of Lead Check ${ }^{\circledR}$ screening on overcoatings with and without

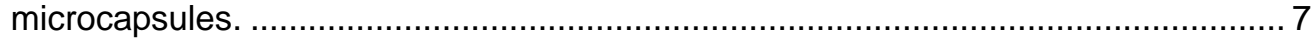

6. Cutting diagram for visual and ASTM E 1728 lead wipe testing .................................. 8

7. ASTM E1728 lead dust wipe results from Set 1: microcapsules applied with Baker Film Applicator.

8. ASTM E1728 lead dust wipe results from Set 2: microcapsules applied with Baker Film Applicator.

9. ASTM E1728 lead dust wipe test results with various microcapsules applied using a brush, including control coatings (without microcapsules).

10. ASTM E1728 results with microcapsules applied using a brush with expanded scale to show comparison of various microcapsule-laden coatings. ....................... 13

11. Preexisting condition of painted exterior wood siding . ............................................... 16

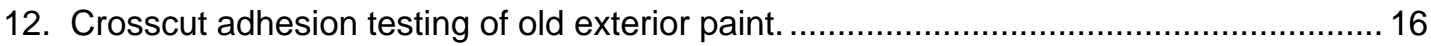

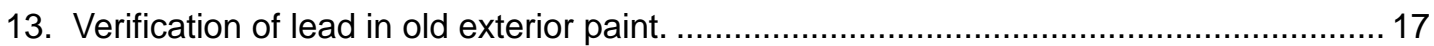

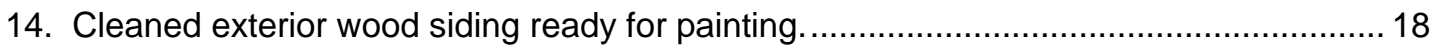

15. Polybutene and calcium hydroxide microcapsules. .................................................. 19

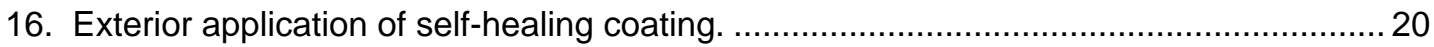

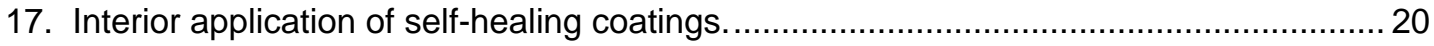

18. Scribed test area for wipe testing of self-healing coating. ............................................ 22

\section{Tables}

1. ASTM E1728 results from Set $1-\mathrm{Ca}(\mathrm{OH})$ microcapsules applied with drawdown device (Baker Film Applicator).

2. ASTM E1728 results from Set $2-\mathrm{Ca}(\mathrm{OH})$ microcapsules applied with drawdown

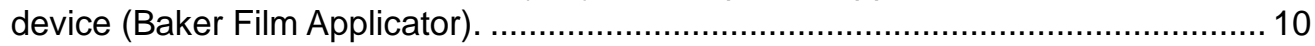

3. ASTM E1728 results from $\mathrm{Ca}(\mathrm{OH})$ microcapsules applied with brush. .......................... 10

4. ASTM E 1728 results from polybutene microcapsules applied with brush. ...................... 11 
5. ASTM E 1728 results from Set $1-50 / 50$ combination of $\mathrm{Ca}(\mathrm{OH})$ and polybutene using a drawdown device (Baker Film Applicator).

6. ASTM E 1728 results from Set $2-50 / 50$ combination of $\mathrm{Ca}(\mathrm{OH})$ and polybutene using a drawdown device (Baker Film Applicator).

7. ASTM E1728 results from $50 / 50$ combination of $\mathrm{Ca}(\mathrm{OH})$ and polybutene applied with brush.

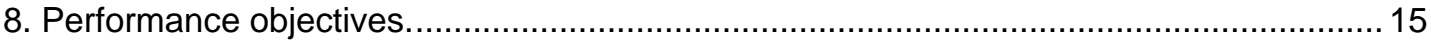

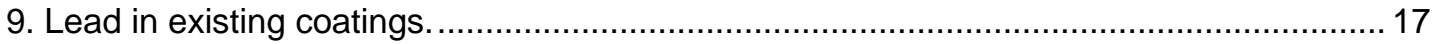

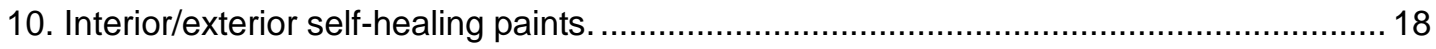

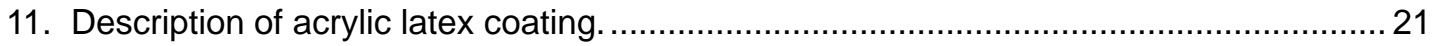

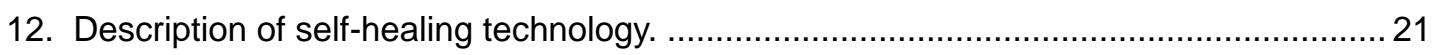

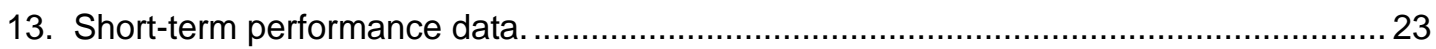

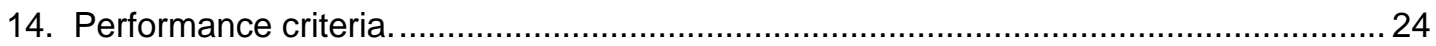

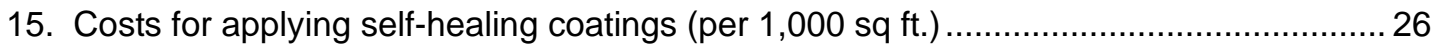

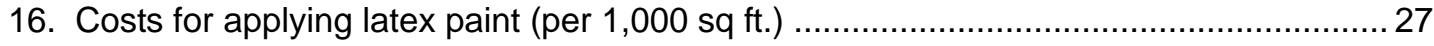




\section{Conversion Factors}

U.S. standard units of measure can be converted to $\mathrm{SI}^{*}$ units as follows:

\begin{tabular}{|c|c|c|}
\hline Multiply & By & To Obtain \\
\hline acres & $4,046.873$ & square meters \\
\hline cubic feet & 0.02831685 & cubic meters \\
\hline cubic inches & 0.00001638706 & cubic meters \\
\hline degrees (angle) & 0.01745329 & radians \\
\hline degrees Fahrenheit & $(5 / 9) \times\left({ }^{\circ} \mathrm{F}-32\right)$ & degrees Celsius \\
\hline degrees Fahrenheit & $(5 / 9) \times\left({ }^{\circ} \mathrm{F}-32\right)+273.15$ & kelvins \\
\hline feet & 0.3048 & meters \\
\hline gallons (U.S. liquid) & 0.003785412 & cubic meters \\
\hline horsepower (550 ft-lb force per second) & 745.6999 & watts \\
\hline inches & 0.0254 & meters \\
\hline kips per square foot & 47.88026 & kilopascals \\
\hline kips per square inch & 6.894757 & megapascals \\
\hline miles (U.S. statute) & 1.609347 & kilometers \\
\hline pounds (force) & 4.448222 & newtons \\
\hline pounds (force) per square inch & 0.006894757 & megapascals \\
\hline pounds (mass) & 0.4535924 & kilograms \\
\hline square feet & 0.09290304 & square meters \\
\hline square miles & $2,589,998$ & square meters \\
\hline tons (force) & $8,896.443$ & newtons \\
\hline tons ( 2,000 pounds, mass) & 907.1847 & kilograms \\
\hline yards & 0.9144 & meters \\
\hline
\end{tabular}

* SI: Système International d'Unités (International System of Measurement). 


\section{Preface}

This technology demonstration was conducted for Headquarters, Department of the Army under Program Element (PE) 063728A, "Environmental Technology Demonstration Project 002, "Environmental Compliance Technology"; Work Unit CF-M B101, "Cost Effective Technologies to Reduce, Characterize, Dispose, and Reuse Sources of Lead Hazards.” Bryan Nix, ACS (IM)-FDF, was the Technical Monitor.

The work was performed by the Materials and Structure Branch (CF-M) of the Facilities Division (CF) Construction Engineering Research Laboratory (CERL). The CERL Principal Investigator was Dr. Ashok Kumar. Part of this work was done by Corrosion Control Consultant and Laboratories (CCC\&L), under Contract DACA4203-P-0086. The contributions of Tim Race for field testing of this technology and Tyson Masar, Tim Kang, Mike Garcia, and James Soldenwagner for the laboratory research and testing phase of the technology development are greatly appreciated. The Technical Editor was Marsha Gay, Information Technology Laboratory Vicksburg. Martin J. Savoie is Chief, CEERD-CF-M and L. Michael Golish is Chief, CF. The Technical Director of the Installation Operations Business Area is Gary W. Schanche (CV-T), and the Director of CERL is Dr. Alan W. Moore.

CERL is an element of the U.S. Army Engineer Research and Development Center (ERDC), U.S. Army Corps of Engineers. The Commander and Executive Director of ERDC is COL James R. Rowan, EN, and the Director is Dr. James R. Houston. 


\section{Executive Summary}

Deteriorated lead-based paint (LBP) poses a serious health risk to building occupants, particularly children. Abatement is intended to eliminate the health risk associated with LBP. Abatement methods include encasement of the substrate, removal, and overcoating with approved encapsulating coatings. Removal includes removal of the lead-painted substrate or removal of just the LBP itself. However, paint removal methods are generally reserved for limited areas and for surfaces where historic preservation requirements may apply. Paint removal techniques demand high levels of control and worker protection, and also may generate significant amounts of hazardous waste.

Self-healing coatings are latex coatings containing microencapsulated liquid healants. The coatings are applied over existing LBP. If the coating cracks, or is scratched or cut, the microcapsules rupture and release the liquid healants. The liquid flows into the damaged area and rapidly cures to form a solid material that seals the damaged area. The self-healing mechanism ensures the continued containment of hazardous lead even when the overcoat sustains damage. The selfhealing mechanisms are projected to prolong the useful life of the coating.

Laboratory experiments were performed to optimize the efficacy of self-healing coatings by testing types and amount of microcapsule additives containing liquid film formers to commercially available latex paint. The experiments resulted in the identification of a 30 percent dry weight combination of microcapsules containing polybutene and those containing calcium hydroxide in a dry paint film as the best performing self-healing coating in terms of lead dust suppression.

A wooden building with existing LBP at the former Fort Ord, Marina, CA, was chosen for the evaluation of the performance of self-healing overcoatings, versus plain latex paint overcoatings. Based on the successful results of the laboratory experiment, the combination of microcapsules containing polybutene and calcium hydroxide were mixed into latex paint. The resulting mixture was brush-applied over LBP onto $50 \mathrm{sq} \mathrm{ft}$ of an interior wooden surface and $50 \mathrm{sq} \mathrm{ft}$ of exterior wooden surface both with existing LBP. When the dried self-healing coatings were cut, the microcapsules released the lead dust suppression and coating repair compounds into the

cut areas. The efficacy of the resulting self-healing overcoating was evaluated by the ASTM E 1728 wipe test after a series of cuts had been made in several 100-sq- 
$\mathrm{cm}$ areas. The overcoatings with the self-healing microcapsules were compared with the controls, plain latex paint overcoatings (i.e., coatings without self-healing microcapsules), which were also painted over $50 \mathrm{sq} \mathrm{ft}$ of existing LBP on both the interior and exterior of the building.

The average wipe test lead level for interior surfaces coated with self-healing coating was $45 \mu \mathrm{g} / \mathrm{ft}^{2}$ lead, or the same as the method detection limit. Tests on interior control surfaces were only slightly higher with an average of $60 \mu \mathrm{g} / \mathrm{ft}^{2}$ lead. The tests on interior surfaces show a 25 percent reduction in lead dust.

The average wipe test lead level for exterior surfaces coated with self-healing coating was $140 \mu \mathrm{g} / \mathrm{ft}^{2}$ lead. Tests on exterior control surfaces were significantly higher with an average of $1,300 \mu \mathrm{g} / \mathrm{ft}^{2}$ lead. The tests on exterior surfaces demonstrate the short-term efficacy of the self-healing coating, i.e., an 89 percent reduction in lead dust.

The unit area cost of self-healing coatings was shown to be $\$ 3.71 / \mathrm{sq} \mathrm{ft}$, and the unit area cost of plain latex coatings was $\$ 3.48 / \mathrm{sq} \mathrm{ft}$. Although the addition of the microcapsules results in an increase of 6.2 percent to the cost of overcoating, the selfhealing overcoatings showed a 95 percent reduction in lead dust over the controls in the laboratory. In the field demonstration, they resulted in 25 percent to 89 percent reduction in lead dust performance, with a mean lead reduction of 60 percent. On the basis of lead dust reduction, the service life of the coating is extended by 60 percent.

The generally accepted maximum life of plain latex paint overcoatings is 10 years on exterior surfaces, due to degradation via the ultraviolet light (UV) component of sunlight. On interior coatings, the maximum service life is only 4 years, due to wear and tear by young children. Thus, the use of self-healing coatings has been projected to extend the coating lives 11.2 to 16 years for exterior coatings and 2.4 years for interior coatings, when used in child-accessible areas. For plain latex overcoatings, the unit area costs per year of coating life range from $\$ 0.34 / \mathrm{sq} \mathrm{ft} /$ year to $\$ 0.50 / \mathrm{sq} \mathrm{ft} /$ year for exterior coatings and $\$ 0.87 \mathrm{sq} \mathrm{ft} /$ year for interior coatings. For self-healing overcoatings, the potential unit area costs per year range from $\$ 0.23 / \mathrm{sq}$ $\mathrm{ft} /$ year to $\$ 0.33 / \mathrm{sq} \mathrm{ft} /$ year for exterior coatings, and $\$ 0.58 \mathrm{sq} \mathrm{ft} /$ year for interior coatings in child-accessible areas. In either case, the cost benefit from using self-healing coatings for both exterior and interior surfaces, is projected to be 33 percent over the 11.2 to 16 years for exterior coatings, or over 6.4 years for interior coatings in childaccessible areas, compared with plain latex overcoatings. Self-healing coatings should be used only for overcoating LBP on exterior surfaces or interior surfaces in high wear-and-tear areas. 


\section{Introduction}

\section{Background}

This report addresses the environmental problem of control of lead-based paint (LBP) hazards on buildings. Deteriorated LBP poses a serious health risk to building occupants, particularly children. Abatement is intended to eliminate the health risk associated with LBP. Abatement methods include encasement of the substrate, removal, and overcoating with approved encapsulating coatings. Removal includes removal of the lead-painted substrate or removal of just the LBP itself. However, paint removal methods are generally reserved for limited areas and for surfaces where historic preservation requirements may apply. Paint removal techniques demand high levels of control and worker protection, and also may generate significant amounts of hazardous waste.

The expected benefit of this technology is the cost-effective abatement of LBP on building surfaces. The material and process described herein represent a potential new technology for LBP abatement. The demonstration was performed on interior wood columns and windows and exterior wood siding at the former Fort Ord, Marina, CA.

\section{Objective}

The purpose of the demonstration was to evaluate the cost and performance of selfhealing coatings to control lead hazards on wooden building surfaces.

\section{Approach}

Laboratory experiments were performed to optimize the efficacy of microcapsule additives containing liquid film formers to commercially available latex paint to produce self-healing coatings. A wooden building with existing LBP at the former Fort Ord, CA, was chosen for the evaluation of the performance of self-healing overcoatings compared with plain latex paint overcoatings. A field adhesion test (American Society for Testing and Materials [ASTM] D3359) (ASTM 2002B) was performed to 
verify that the existing LBP coatings were suitable for overcoating. Microcapsules containing film-formers and lead dust suppression compounds were mixed into latex paint. The resulting mixture was brush-applied over LBP onto $50 \mathrm{sq} \mathrm{ft}^{*}$ of an interior wooden surface and $50 \mathrm{sq} \mathrm{ft}$ of exterior wooden surface both with existing LBP. When the dried self-healing coatings were cut, the microcapsules released the lead dust suppression and coating repair compounds into the cut areas. The efficacy of the self-healing overcoating was evaluated by the ASTM E1728 wipe test (ASTM 2002a) after a series of cuts had been made in several 100 sq. cm areas. The overcoatings with the self-healing microcapsules were compared with the controls, plain latex paint overcoatings (i.e., coatings without self-healing microcapsules), which were also painted over $50 \mathrm{sq} f t$ of existing LBP on both the interior and exterior of the building.

\section{Mode of Technology Transfer}

Technology transfer is being accomplished by: (1) a Technology Transfer Implementation Plan supervised by the U. S. Army Environmental Center (AEC); (2) dissemination of Public Works Technical Bulletin (PWTB) 420-70-2, "Installation Lead Hazard Management"; (3) participation in User Groups and Committees such as the Army Lead and Asbestos Hazard Management Team, Federal Lead-Based Paint committee meetings at the Environmental Protection Agency (EPA) or U.S. Department of Housing and Urban Development (HUD), and ASTM Committee E06.23 on Lead Hazards Associated with Buildings; and (4) websites maintained by the Office of the Assistant Chief of Staff for Installation Management (ACSIM) [http://www.hqda.army.mil/acsimweb/fd/policy/facengcur.htm], AEC [http://aec. army. mil/usaec/], and the U. S. Army Engineer Research and Development Center, Construction Engineering Research Laboratory (ERDC/CERL) [http:// www.cecer.army.mil], as well as the Hands-on-Skills Training (HOST) website [http://www.hqda.army.mil/acsimweb/fd/policy/host/index.htm].

\footnotetext{
* A table of factors for converting non-SI units of measurement to SI units is found on page vii.
} 


\section{Technology Description}

\section{Technology Development and Application}

The intended use of self-healing coatings as evaluated herein is the abatement of interior and exterior lead-coated architectural surfaces. The technology is applicable to the abatement of all types of architectural coatings including alkyd and latex types. The target contaminants are lead compounds used in architectural coatings as hiding and coloring pigments and as agents to promote drying of certain types of coatings. Self-healing coatings are latex coatings containing microencapsulated liquid healants applied over existing LBP. The self-healing coatings work by overcoating the lead-containing paint. If the coating cracks or is scratched or impacted, the microcapsules will rupture and release the liquid healants. The liquid flows into the damaged area and forms a solid material (calcium carbonate) that seals the damaged area. The self-healing mechanism ensures the continued containment of hazardous lead even when the overcoat sustains damage. The self-healing mechanism may also prolong the useful life of the coating.

\section{Laboratory Testing}

The use of overcoatings is one possible abatement method for controlling the exposure to lead from LBP. The object of the laboratory experiments was to determine the effectiveness of different types of microcapsules used to make self-healing coatings. This entailed providing observations and numerical results for the amount of lead dust exposed when an overcoating with microcapsules is breached.

All of the microcapsules were tested in the same manner. They were mixed with latex paint and applied at a thickness of 8 mils over a coat of 4-mil-thick LBP. All of the samples were then covered with an 8-mil-thick layer of plain latex over-coating. After the overcoat was allowed to dry, the samples were scribed with a razor blade. When cut or scratched, the paint coating layer, along with some of the microcapsules, was broken. The rupture of the microcapsules should have been sufficient to release their payloads; core material was then free to flow into the grooves created by the cut. The contents of the microcapsules should have then formed a protective barrier, which would not have allowed any lead dust through. The dried plates 
were then tested three ways: (1) visually, (2) with the use of a LeadCheck ${ }^{\circledR}$ swab (Hybrivet Systems, Natick, MA) and (3) wiped for lead dust concentration levels using ASTM E1728-95 "Standard Practice for Field Collection of Settled Dust Samples using Wipe Sampling Methods for Lead Determination by Atomic Spectrometry Techniques," (ASTM 2002a).

Laboratory test samples were made by painting a 7 - by 2.5 - by 0.2 -in. wood slab. The wood was coated with a 6 -mil wet layer of LBP (72 percent lead carbonate, 20 percent linseed oils, and 7 percent lead/cobalt drier). This layer was applied using an adjustable Baker Film Applicator (Elcometer, Manchester, England) with an area of 3- by 2.5-in. The LBP layer dried to about 4 mils. After the wooden sample was coated with LBP, an overcoating layer was applied. This layer was applied at 8 mils, wet, using the Baker film applicator.

For all control samples, this layer was composed of plain latex paint. The paint used in all experiments was Four Seasons Trim Enamel Gloss Acrylic Latex (White 024-1791, MAB Paints, Broomall, PA 19008). This particular paint has a 58/100 solid-to-solvent ratio. Previous data showed that a 30/70 dry weight ratio of microcapsules to paint provided the most protection. Therefore, the dry capsules were mixed with the paint at a weight percentage ratio of 20 percent capsules to 80 percent paint.

The microcapsules were hand mixed with the paint by gently stirring with a spoon. Four types of microcapsules were tested. To test the microcapsules, a number of experiments were performed. The microcapsules used were all 63-150 microns in diameter and with a urea formaldehyde shell. The core ingredients differed in each type. 3M Technologies supplied one of the microcapsules types with tung oil as the core constituent. Thies Technologies supplied the other three microcapsules with core ingredients of $\mathrm{Ca}(\mathrm{OH})$, polybutene/sanitizer, and spar varnish/tung oil, respectively. The microcapsule layer was allowed to dry for 24 hours before a final coat of 8-mil-thick, plain latex paint was added. This overcoat was applied on both the control samples and the microcapsule samples. This process was repeated for each set of data. Each time, 3-9 samples were made of each microcapsule type, and 3-9 were used as controls. The samples were then compared against each other to determine the total effect of the microcapsules. Figure 1 is a schematic illustrating the various layers of paint on the samples. An optical micrograph showing a transverse section of one of the self-healing coatings over LBP is shown in Figure 2. 


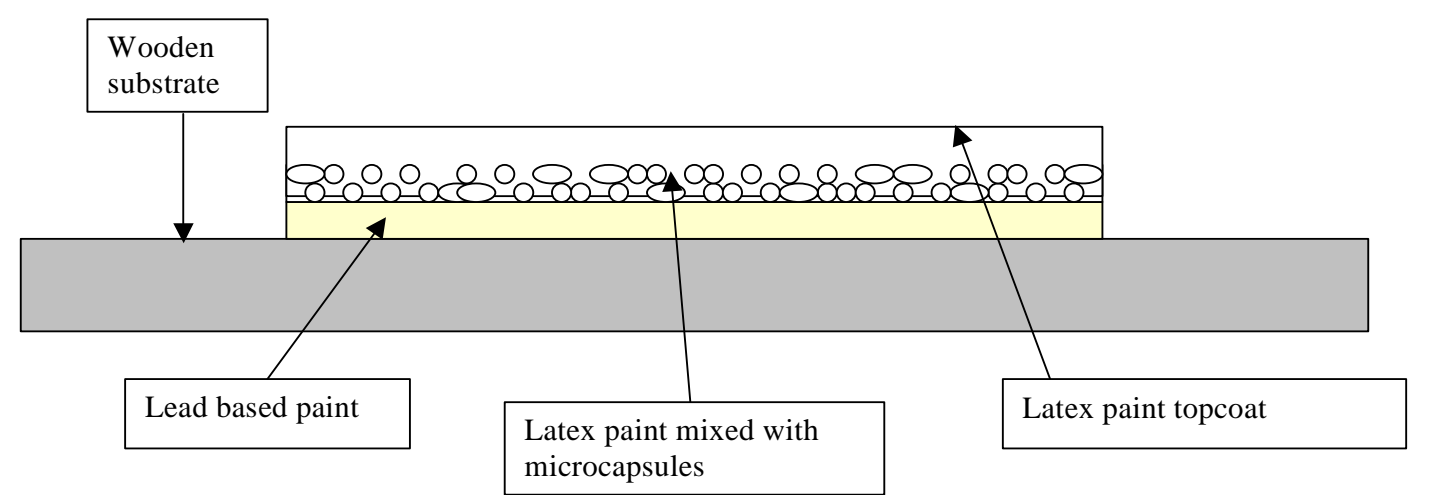

Figure 1. Layer technique used in applying microcapsules.

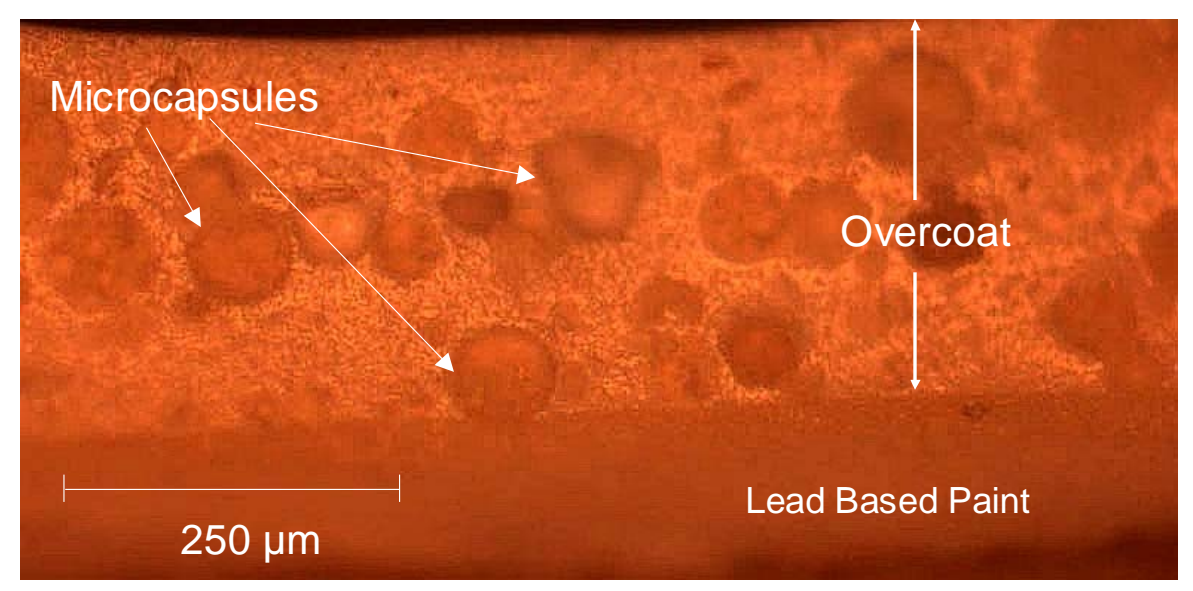

Figure 2. Optical micrograph of microcapsules within the self-healing overcoating for the LBP.

The efficacy of release mechanisms for core constituents of the microcapsules were studied in the laboratory, and examples are shown in Figures 3a and 3b. Figure 3a shows the results of one of the microcapsule release studies in which microcapsules containing red dye were incorporated into a latex paint coating applied to a piece of rubber that was subsequently twisted, resulting in the formation of a crack in the coating. The formation of the crack ruptured one of the microcapsules and caused the red dye to flow. A second mechanism of microcapsule core constituent release is illustrated in Figure 3b. The red dye microcapsules were incorporated into a latex coating applied to a wooden substrate. The dried coating was then cut with a razor blade, which also broke open the microcapsules and resulted in the flow of red dye into the damaged area. "Self-healing" materials that restore the integrity of the original paint film will also flow into cracked, scratched, or cut areas via these same mechanisms. 


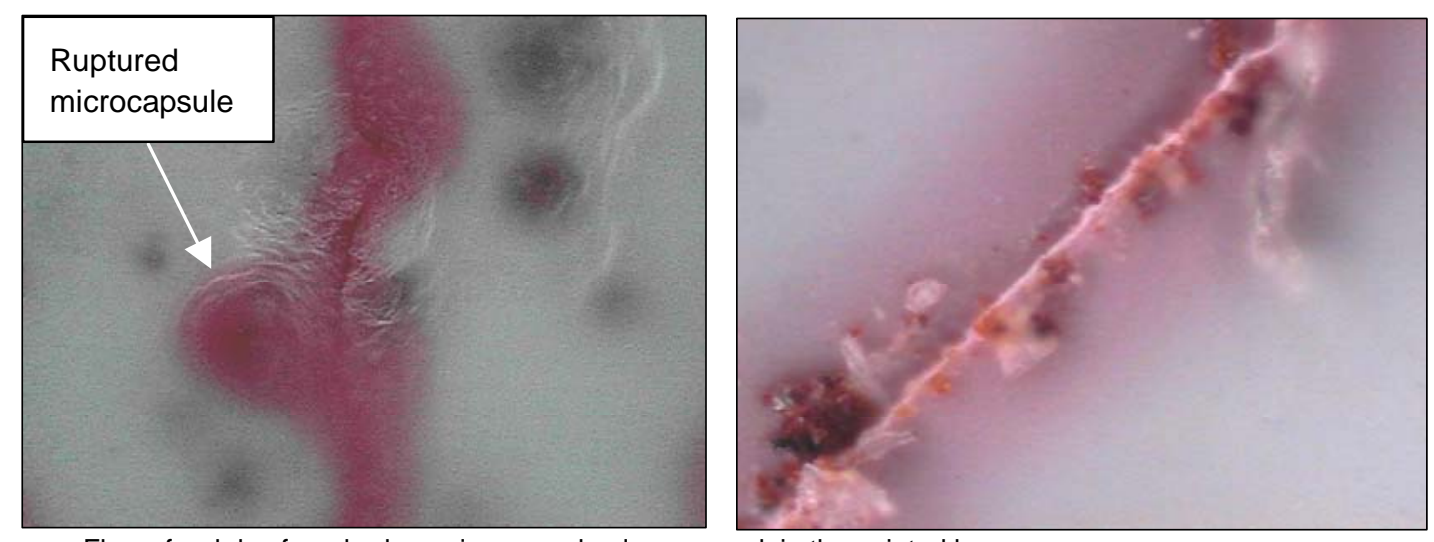

a. Flow of red dye from broken microcapsule along a crack in the painted layer

b. Release of red dye into a cut area of the coating.

Figure 3. Release of red dye from ruptured microcapsules illustrating self-healing mechanism.

Once a set of samples was painted and completely dry, some were set aside to be tested visually. The following procedure was used for this screening process. Three identical X-marks, each with exactly 1.5 in. long, were cut in each sheet with a razor blade (Figure 4). The cut penetrated completely through all of the layers. Each sample was examined carefully under the microscope to confirm visually that the microcapsules were broken. Next, the amount of dust created and the contents of the microcapsules that were visibly flowing was observed. A LeadCheck Swab was then used to try to determine the amount of lead dust getting through the cuts. These swabs are designed to turn red when they encounter lead at levels as low as $5,000 \mathrm{ppm}$ (Figure 5). One X-cut was swabbed immediately after being cut; the second X-cut was tested $10 \mathrm{~min}$ after the cut; and the final cut was tested $3 \mathrm{hr}$ after being cut. An additional 1/2-in. single cut was made in each sample to be tested in a couple of days. This time interval was used to determine how quickly the microcapsule film-formers became effective, and to see how their performance changed over time. If the microcapsule-laden coatings indicated decreased levels of lead dust compared to those of the controls, the samples were selected for the next level of testing. 


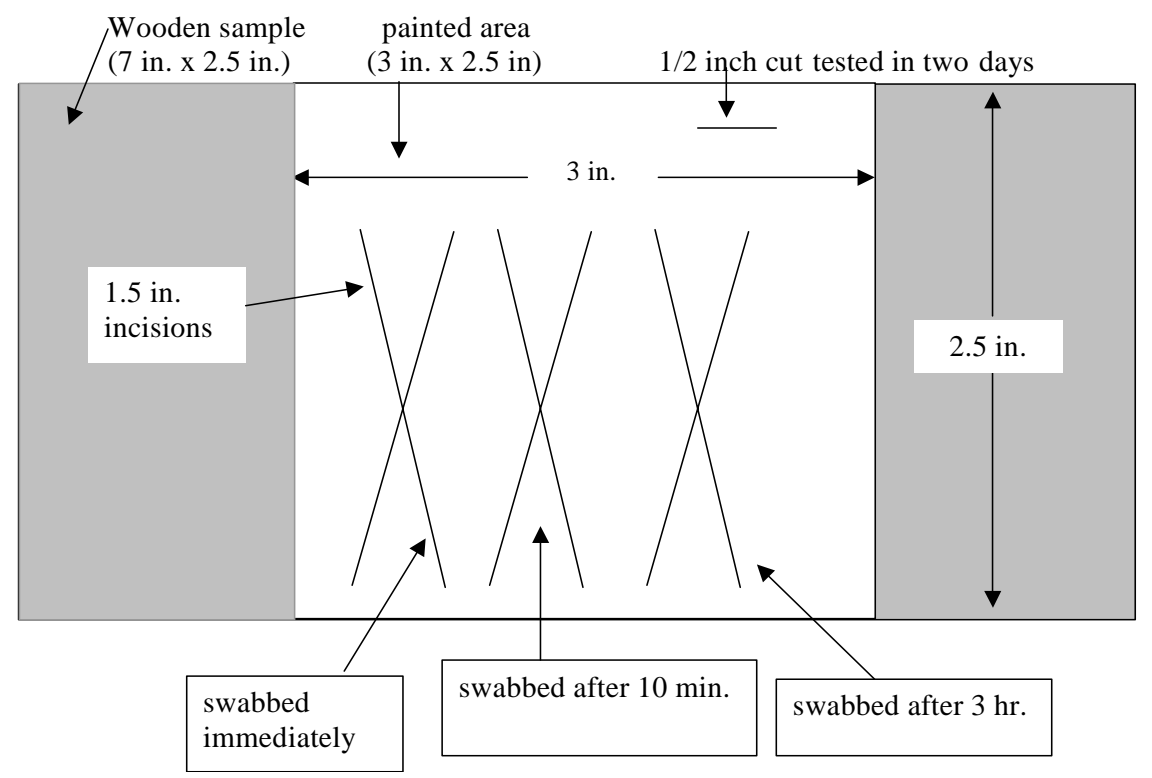

Figure 4. Cutting diagram for Lead Check® screening.

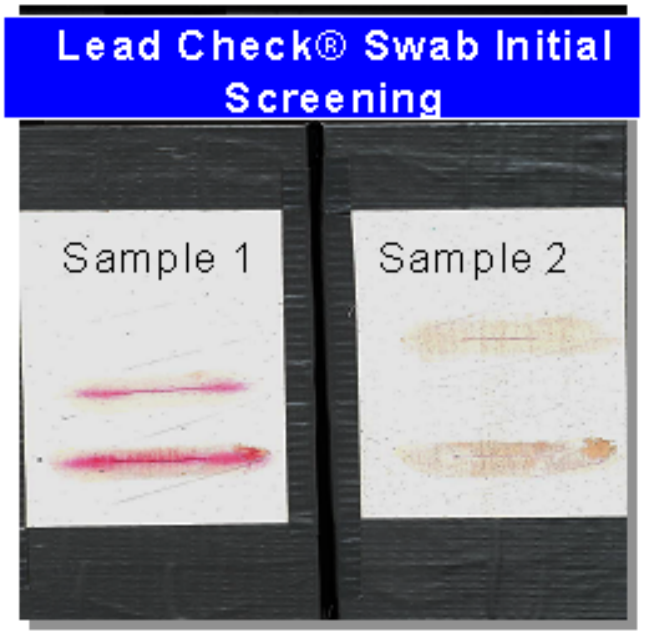

Both overcoating samples on the left were scribed. The scribed areas were swiped with Lead Check ${ }^{\circledR}$ Swabs

- Sample 1: Pink color indicates presence of lead at $>10 \mathrm{ppm}$

- Sample 2: Self-healing microcapsules in latex overcoating suppress lead dust as indicated by lack of pink color.

Figure 5. Comparison of Lead Check® screening on overcoatings with and without microcapsules.

To quantify the lead dust concentration levels, a wipe test was performed on each sample. Six 1.5-in. incisions were made on the sample using a razor blade. Next, three 3 -in. crosshatches were made across the vertical cuts. Figure 6 demonstrates the cutting procedure. Each sample was wiped according to ASTM E 1728-95 "Standard Practice for Field Collection of Settled Dust Samples using Wipe Sampling Methods for Lead Determination by Atomic Spectrometry Techniques," using standard "ghost wipes" (i.e, prepackaged paper towelettes soaked in a wetting agent). The wipe samples were then placed into Falcon 50-m disposable test tubes and shipped to Analytical Environmental Services Inc., Atlanta, GA. Analytical Envi- 
ronmental Services used the flame atomic absorption spectroscopy, Method: NIOSH 7082 for lead detection (NIOSH 1994). This method can detect lead levels to a sensitivity of $2.5 \mu \mathrm{g}$. Some of these samples were tested to a sensitivity of only $10 \mu \mathrm{g}$.

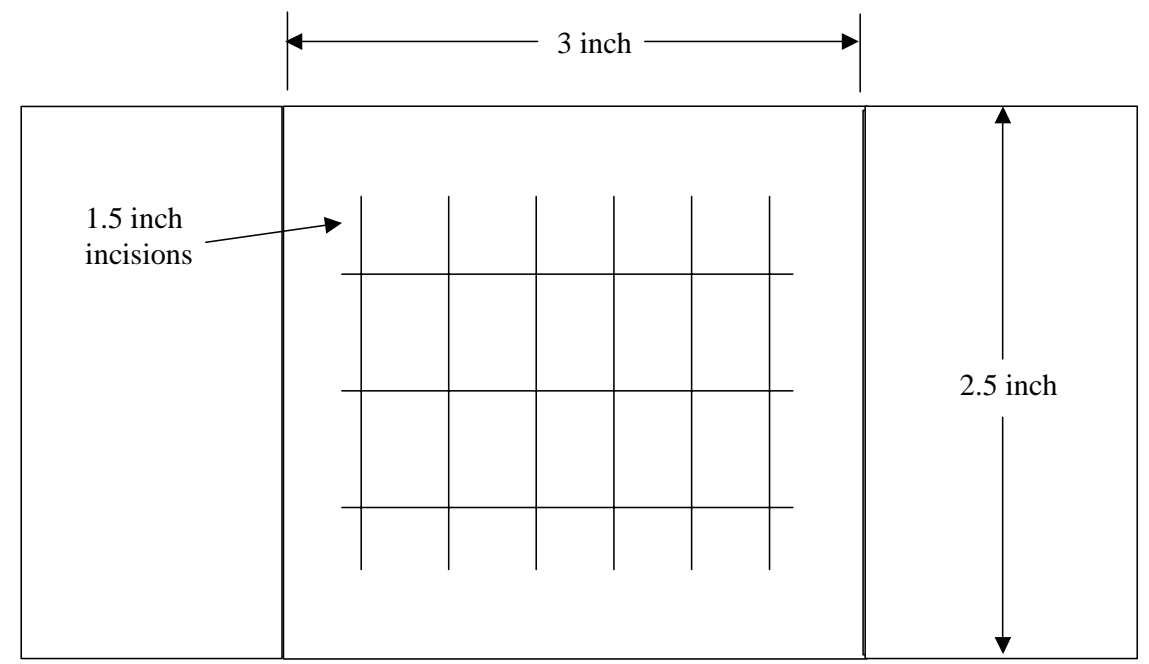

Figure 6. Cutting diagram for visual and ASTM E 1728 lead wipe testing.

Once significant improvements in lead dust suppression were obtained, field application issues were considered. Due to the larger areas of buildings and interior walls, a drawdown device is not practical. Therefore, three types of application methods were tested: spraying, rolling, and brushing. In all cases, the microcapsules were mixed using the same method as in the previous laboratory experiments, i.e., hand mixed at a 20/80 weight ratio with the paint. Applying this mixture with a spray gun was quickly ruled out, because the microcapsules broke on impact with the wood. Also, the microcapsules tended to clog up the gun. Both rolling and brushing had better results. The microcapsules seemed to be fairly well spread out in both cases. The brushing technique applied a slightly smoother surface, but also had the negative aspect of small ridges. There were a few small clumps of microcapsules when they were rolled on. The only major problem with these two techniques was that they were applying the microcapsules mixture too thinly. The layer was only about 3 mils thick, and it was not providing enough protection against the lead. To rectify this situation, two layers of microcapsules/paint mixture were applied.

\section{Results of Laboratory Testing}

Tables 1 through 7 show the results of the ASTM E1728 lead wipe tests on the overcoatings with the various types of microcapsules applied by drawdown and brush. 
The microcapsules that were most effective against lead dust were the $\mathrm{Ca}(\mathrm{OH})$ microcapsules and the polybutene microcapsules. The $3 \mathrm{M}$ microcapsules provided slightly more protection against lead dust than the controls. The tung oil microcapsules provided the least amount of protection against lead dust. The $\mathrm{Ca}(\mathrm{OH})$ microcapsules were the most effective microcapsules when used separately. They did not perform as well immediately after the cut was made, but they outperformed all other microcapsules types at the $10 \mathrm{~min}$ and 3-hr mark. Ideally, the $\mathrm{Ca}(\mathrm{OH})$ released from the microcapsules would react with $\mathrm{CO}_{2}$ in the air to form calcium carbonate, a hard, durable substance. The calcium carbonate would then act as a barrier to prevent lead dust from escaping. This process takes a while to complete, and this fact may contribute to the performance of the microcapsules immediately after the cut is made.

Tables 1 and 2 show how well the $\mathrm{Ca}(\mathrm{OH})$ microcapsule samples performed against the controls when applied using the draw down technique via Baker Film Applicator (33 percent lead dust suppression). Table 3 shows the performance of the $\mathrm{Ca}(\mathrm{OH})$ microcapsules when applied with a brush (94 percent lead dust suppression).

The polybutene microcapsules were also efficient in lead suppression. They proved to be very effective in preventing most of the lead dust from reaching the surface. They were the most effective microcapsules immediately after an incision was made. As polybutene has a relatively low viscosity, it filled in the cuts quickly. Table 4 shows how well they performed against controls when they were applied with a 2.5in. brush (94 percent lead dust suppression).

The most effective lead suppression mixture was actually a 50/50 mixture of the highest performing microcapsules: polybutene and $\mathrm{Ca}(\mathrm{OH})$. This combination of microcapsules worked very well over every time interval, and they almost completely filled in the cuts made in the paint layers when applied by drawdown using a Baker Film Applicator. Tables 5 and 6 compare the performance of the mixture with that of the controls (52 and 62 percent lead dust suppression). In both sets of tests, the mean for the microcapsule samples is less than half of that of the controls. Figures 7 and 8 are plots that show how well the 50/50 combination performed against the other microcapsules as well as controls when applied with a Baker Film Applicator. 
Table 1. ASTM E1728 results from Set $1-\mathrm{Ca}(\mathrm{OH})$ microcapsules applied with drawdown device (Baker Film Applicator).

\begin{tabular}{|c|c|c|c|c|c|}
\hline Code & $\begin{array}{l}\text { Sample } \\
\text { Microcapsule Type }\end{array}$ & $\begin{array}{l}\mathrm{Pb} \text { level } \\
\mu \mathrm{g} / \mathrm{ft}^{2}\end{array}$ & Code & $\begin{array}{l}\text { Control } \\
\text { Microcapsule Type }\end{array}$ & $\begin{array}{l}\mathrm{Pb} \text { level } \\
\mu \mathrm{g} / \mathrm{ft}^{2}\end{array}$ \\
\hline B1 & $\mathrm{CaOH} 1$ & 18 & C1 & Control-1 & 25 \\
\hline B2 & $\mathrm{CaOH} 2$ & 14 & $\mathrm{C2}$ & Control-2 & 39 \\
\hline B3 & $\mathrm{CaOH} 3$ & 16 & C3 & Control-3 & 40 \\
\hline B4 & $\mathrm{CaOH} 4$ & 13 & C4 & Control-4 & 19 \\
\hline B5 & $\mathrm{CaOH} 5$ & 30 & C5 & Control-5 & 24 \\
\hline \multirow[t]{3}{*}{ B6 } & $\mathrm{CaOH} 6$ & 36 & C6 & Control-6 & 43 \\
\hline & $A \vee G=$ & 21.16667 & & $A \vee G=$ & 31.66667 \\
\hline & Stan. Dev. & 9.516652 & & Stan. Dev. & 10.15218 \\
\hline
\end{tabular}

Table 2. ASTM E1728 results from Set $2-\mathrm{Ca}(\mathrm{OH})$ microcapsules applied with drawdown device (Baker Film Applicator).

\begin{tabular}{|c|c|c|c|c|c|}
\hline Code & $\begin{array}{l}\text { Sample } \\
\text { Microcapsule Type }\end{array}$ & $\begin{array}{l}\mathrm{Pb} \text { level } \\
\mu \mathrm{g} / \mathrm{ft}^{2}\end{array}$ & Code & $\begin{array}{l}\text { Control } \\
\text { Microcapsule Type }\end{array}$ & $\begin{array}{l}\mathrm{Pb} \text { level } \\
\mu \mathrm{g} / \mathrm{ft}^{2}\end{array}$ \\
\hline Bb1 & $\mathrm{CaOH} 1 \mathrm{a}$ & 31 & C1 & Control-1 & 34 \\
\hline $\mathrm{Bb} 2$ & $\mathrm{CaOH} 2 \mathrm{a}$ & 25 & C2 & Control-2 & 42 \\
\hline Bb3 & $\mathrm{CaOH} 3 a$ & 17 & C3 & Control-3 & 21 \\
\hline Bb4 & $\mathrm{CaOH} 4 \mathrm{a}$ & 12 & $\mathrm{C} 4$ & Control-4 & 35 \\
\hline Bb5 & $\mathrm{CaOH} 5 \mathrm{a}$ & 19 & C5 & Control-5 & 34 \\
\hline \multirow[t]{3}{*}{ Bb6 } & $\mathrm{CaOH} 6 \mathrm{a}$ & 24 & C6 & Control-6 & 29 \\
\hline & $A V G=$ & 21.33333 & & $A V G=$ & 32.5 \\
\hline & Stan. Dev. & 6.713171 & & Stan. Dev. & 7.007139 \\
\hline
\end{tabular}

Table 3. ASTM E1728 results from $\mathrm{Ca}(\mathrm{OH})$ microcapsules applied with brush.

\begin{tabular}{|c|c|c|c|c|c|}
\hline Code & $\begin{array}{l}\text { Sample } \\
\text { Microcapsule Type }\end{array}$ & $\begin{array}{l}\mathrm{Pb} \text { level } \\
\mu \mathrm{g} / \mathrm{ft}^{2}\end{array}$ & Code & $\begin{array}{l}\text { Control } \\
\text { Microcapsule Type }\end{array}$ & $\begin{array}{l}\mathrm{Pb} \text { level } \\
\mu \mathrm{g} / \mathrm{ft}^{2}\end{array}$ \\
\hline Da1 & $\mathrm{Ca}(\mathrm{OH}) 1 \mathrm{a}$ & 2.5 & Ca1 & Control 1a & 5.5 \\
\hline $\mathrm{Da} 2$ & $\mathrm{Ca}(\mathrm{OH}) 2 \mathrm{a}$ & 2.5 & $\mathrm{Ca} 2$ & Control 2a & 49 \\
\hline Da3 & $\mathrm{Ca}(\mathrm{OH}) 3 \mathrm{a}$ & 2.5 & $\mathrm{Ca3}$ & Control 3a & 25 \\
\hline Da4 & $\mathrm{Ca}(\mathrm{OH}) 4 \mathrm{a}$ & 2.5 & Ca4 & Control $4 a$ & 199 \\
\hline Da5 & $\mathrm{Ca}(\mathrm{OH}) 5 \mathrm{a}$ & 10.5 & $\mathrm{Ca} 5$ & Control 5a & 42 \\
\hline \multirow[t]{3}{*}{ Da6 } & $\mathrm{Ca}(\mathrm{OH}) 6 \mathrm{a}$ & 2.5 & $\mathrm{Ca} 6$ & Control 6a & 93 \\
\hline & $A \vee G=$ & 3.833333 & & AVG= & 68.91667 \\
\hline & Stan. Dev. & 6.667 & & Stan. Dev. & 130.0833 \\
\hline
\end{tabular}


Table 4. ASTM E 1728 results from polybutene microcapsules applied with brush.

\begin{tabular}{|l|l|l|l|l|l|l|}
\hline Code & $\begin{array}{l}\text { Sample } \\
\text { Microcapsule Type }\end{array}$ & $\begin{array}{l}\text { Pb level } \\
\boldsymbol{\mu g} / \mathrm{ft}^{2}\end{array}$ & Code & $\begin{array}{l}\text { Control } \\
\text { Microcapsule Type }\end{array}$ & $\begin{array}{l}\mathbf{P b} \text { level } \\
\boldsymbol{\mu g} / \mathrm{ft}^{2}\end{array}$ \\
\hline Ba1 & Poly 1 & 8.5 & & Ca1 & Control 1a & 5.5 \\
\hline Ba2 & Poly 2 & 2.5 & & Ca2 & Control 2a & 49 \\
\hline Ba3 & Poly 3 & 2.5 & & Ca3 & Control 3a & 25 \\
\hline Ba4 & Poly 4 & 2.5 & & Ca4 & Control 4a & 199 \\
\hline Ba5 & Poly 5 & 2.5 & & Ca5 & Control 5a & 42 \\
\hline Ba6 & Poly 6 & 2.5 & & Ca6 & Control 6a & 93 \\
\hline & AVG= & 3.5 & & & AVG= & $\mathbf{6 8 . 9 1 6 6 7}$ \\
\hline & Stan. Dev. & 5 & & & Stan. Dev. & 130.0833 \\
\hline
\end{tabular}

Table 5. ASTM E 1728 results from Set $1-50 / 50$ combination of $\mathrm{Ca}(\mathrm{OH})$ and polybutene using a drawdown device (Baker Film Applicator).

\begin{tabular}{|l|l|l|l|l|l|l|}
\hline Code & $\begin{array}{l}\text { Sample } \\
\text { Microcapsule Type }\end{array}$ & $\begin{array}{l}\text { Pb level } \\
\boldsymbol{\mu g} / \mathrm{ft}^{2}\end{array}$ & Code & $\begin{array}{l}\text { Control } \\
\text { Microcapsule Type }\end{array}$ & $\begin{array}{l}\mathbf{P b} \text { level } \\
\boldsymbol{\mu g} / \mathbf{f t}^{2}\end{array}$ \\
\hline D1 & mix 1 & 14 & C1 & Control-1 & 25 \\
\hline D2 & mix 2 & 14 & C2 & Control-2 & 39 \\
\hline D3 & mix 3 & 16 & C3 & Control-3 & 40 \\
\hline D4 & mix 4 & 15 & C4 & Control-4 & 19 \\
\hline D5 & mix 5 & 19 & C5 & Control-5 & 24 \\
\hline D6 & mix 6 & 12 & C6 & Control-6 & 43 \\
\hline & AVG= & 15 & & AVG= & 31.66667 \\
\hline & Stan. Dev. & 2.366432 & & Stan. Dev. & 10.15218 \\
\hline
\end{tabular}

Table 6. ASTM E 1728 results from Set $2-50 / 50$ combination of $\mathrm{Ca}(\mathrm{OH})$ and polybutene using a drawdown device (Baker Film Applicator).

\begin{tabular}{|l|l|l|l|l|l|l|}
\hline Code & $\begin{array}{l}\text { Sample } \\
\text { Microcapsule Type }\end{array}$ & $\begin{array}{l}\mathbf{P b} \text { level } \\
\boldsymbol{\mu g} / \mathrm{ft}^{2}\end{array}$ & & Code & $\begin{array}{l}\text { Control } \\
\text { Microcapsule Type }\end{array}$ & $\begin{array}{l}\mathbf{P b} \text { level } \\
\boldsymbol{\mu g} / \mathbf{f t}^{2}\end{array}$ \\
\hline Db1 & mix 1a & 10 & & Cb1 & Control-1 & 34 \\
\hline Db2 & mix 2a & 11 & & Cb2 & Control-2 & 42 \\
\hline Db3 & mix 3a & 13 & & Cb3 & Control-3 & 21 \\
\hline Db4 & mix 4a & 12 & & Cb4 & Control-4 & 35 \\
\hline Db5 & mix 5a & 12 & & Cb5 & Control-5 & 34 \\
\hline Db6 & mix 6a & 16 & & Cb6 & Control-6 & 29 \\
\hline & AVG= & 12.33333 & & & AVG= & 32.5 \\
\hline & Stan. Dev. & 2.065591 & & & Stan. Dev. & 7.007139 \\
\hline
\end{tabular}




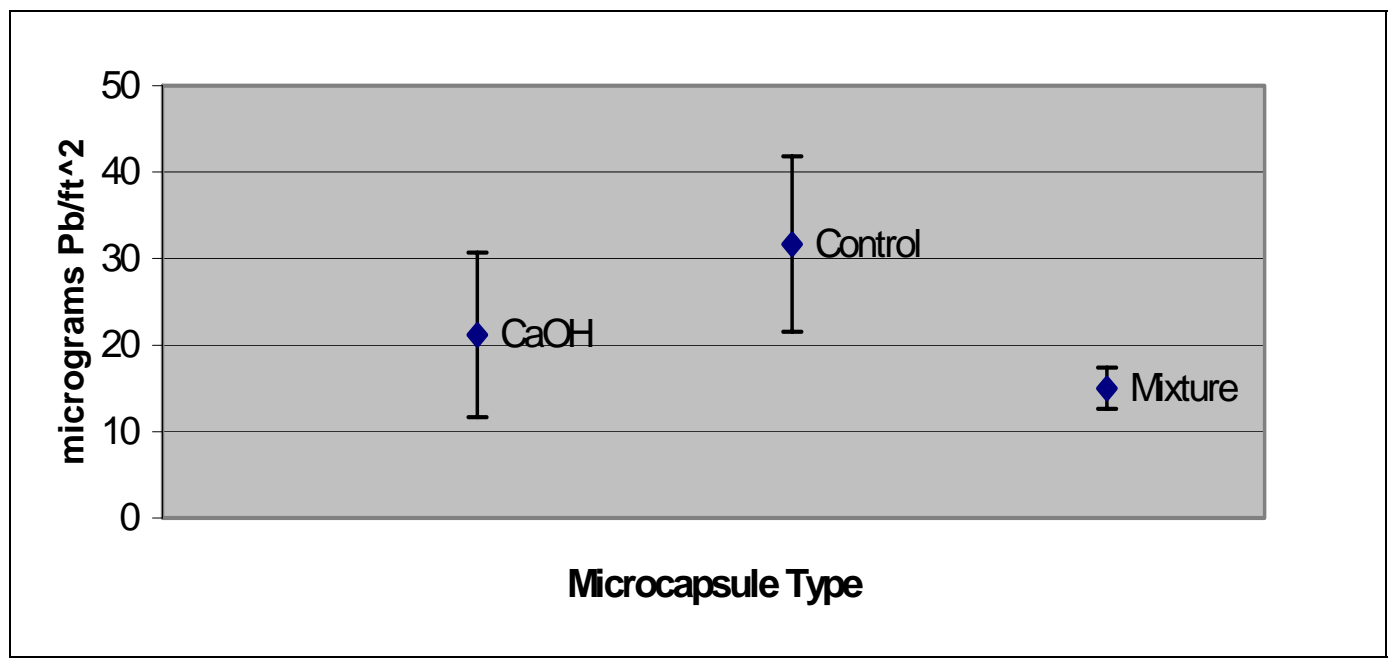

Figure 7. ASTM E1728 lead dust wipe results from Set 1: microcapsules applied with Baker Film Applicator.

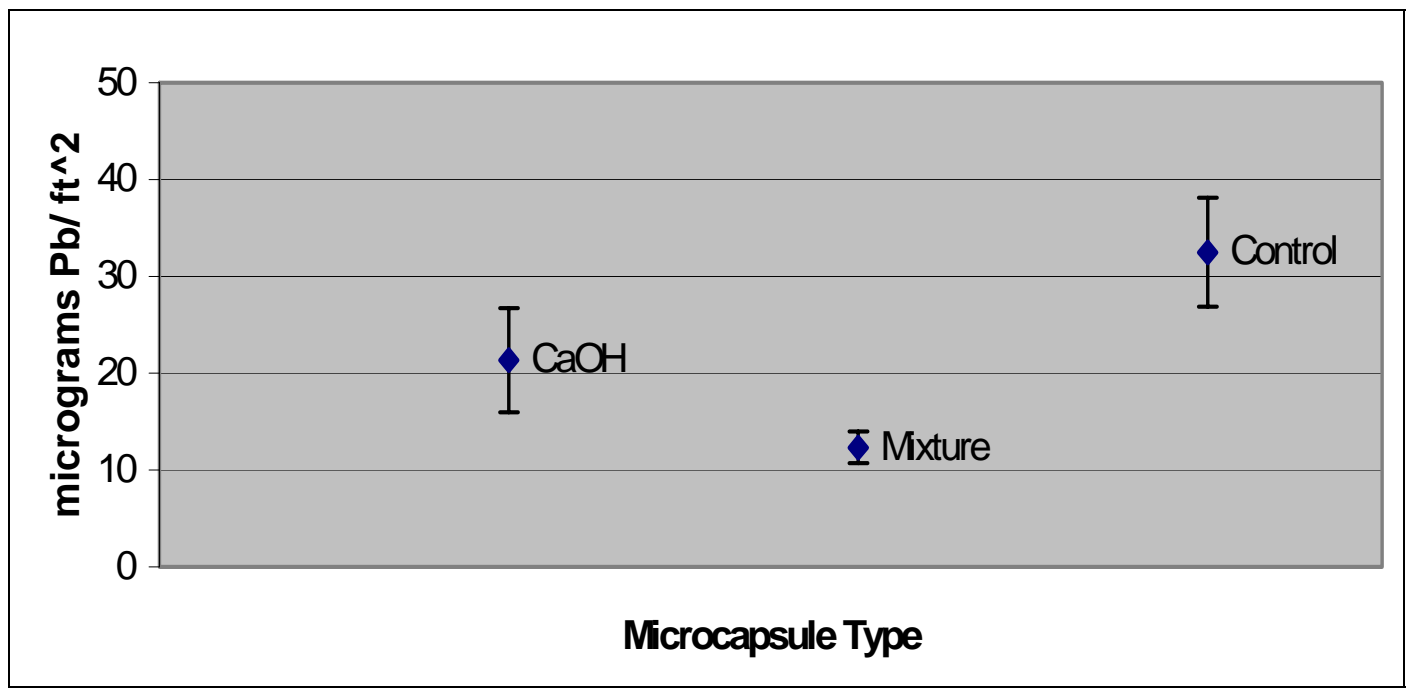

Figure 8. ASTM E1728 lead dust wipe results from Set 2: microcapsules applied with Baker Film Applicator.

As can be seen in Table 7, the mixture of microcapsules (50 percent polybutene and 50 percent $\mathrm{CaOH}$ ) was also very effective when applied by a 2.5-in. polyester brush (95 percent lead dust suppression). The samples with the microcapsules significantly decreased the amount of lead dust on the surface compared with plain latex paint. Figures 9 and 10 are plots that show how the 50/50 mixture compares with the other microcapsules and controls when applied with a brush. 
Table 7. ASTM E1728 results from $50 / 50$ combination of $\mathrm{Ca}(\mathrm{OH})$ and polybutene applied with brush.

\begin{tabular}{|l|l|l|l|l|l|l|}
\hline Code & $\begin{array}{l}\text { Sample } \\
\text { Microcapsule Type }\end{array}$ & $\begin{array}{l}\text { Pb level } \\
\boldsymbol{\mu g} / \mathrm{ft}^{2}\end{array}$ & & Code & $\begin{array}{l}\text { Control } \\
\text { Microcapsule Type }\end{array}$ & $\begin{array}{l}\mathbf{P b} \text { level } \\
\boldsymbol{\mu g} / \mathrm{ft}^{2}\end{array}$ \\
\hline Aa1 & Mix 1a & 2.5 & & Ca1 & Control 1a & 5.5 \\
\hline Aa2 & Mix 2a & 2.5 & & Ca2 & Control 2a & 49 \\
\hline Aa3 & Mix 3a & 2.5 & Ca3 & Control 3a & 25 \\
\hline Aa4 & Mix 4a & 2.5 & Ca4 & Control 4a & 199 \\
\hline Aa5 & Mix 5a & 2.5 & Ca5 & Control 5a & 42 \\
\hline Aa6 & Mix 6a & 6 & Ca6 & Control 6a & 93 \\
\hline & AVG= & $\mathbf{3 . 0 8 3 3 3 3}$ & & & AVG= & $\mathbf{6 8 . 9 1 6 6 7}$ \\
\hline & Stan. Dev. & 2.916667 & & & Stan. Dev. & 130.0833 \\
\hline
\end{tabular}

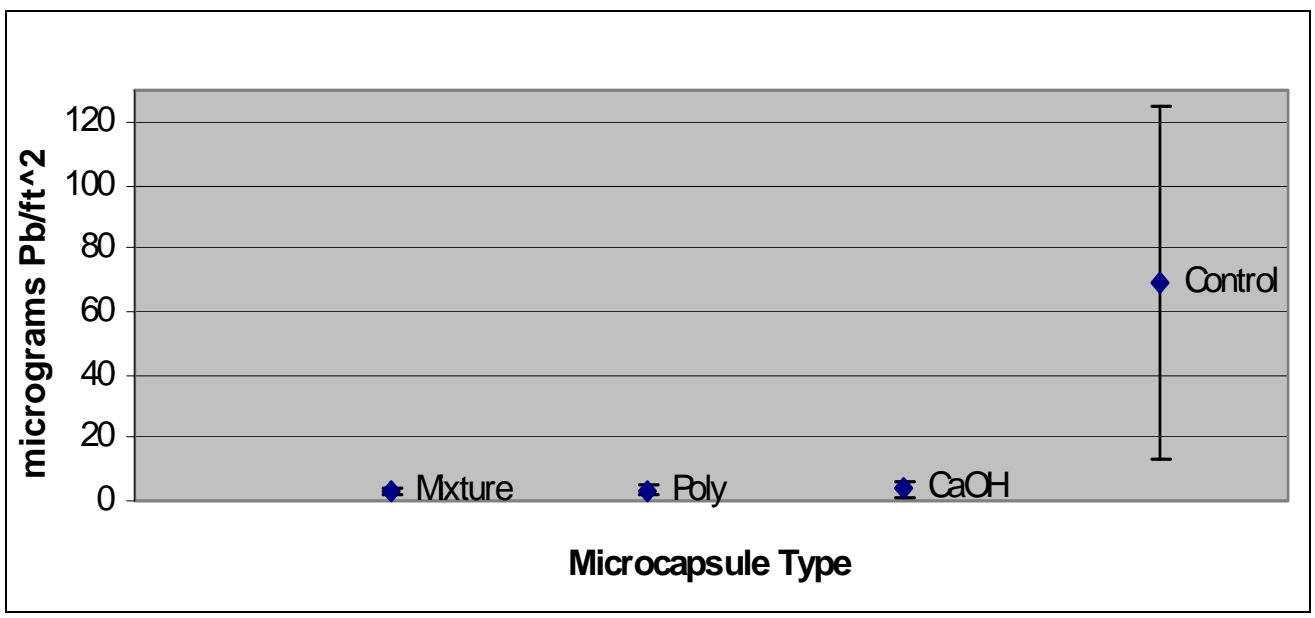

Figure 9. ASTM E1728 lead dust wipe test results with various microcapsules applied using a brush, including control coatings (without microcapsules).

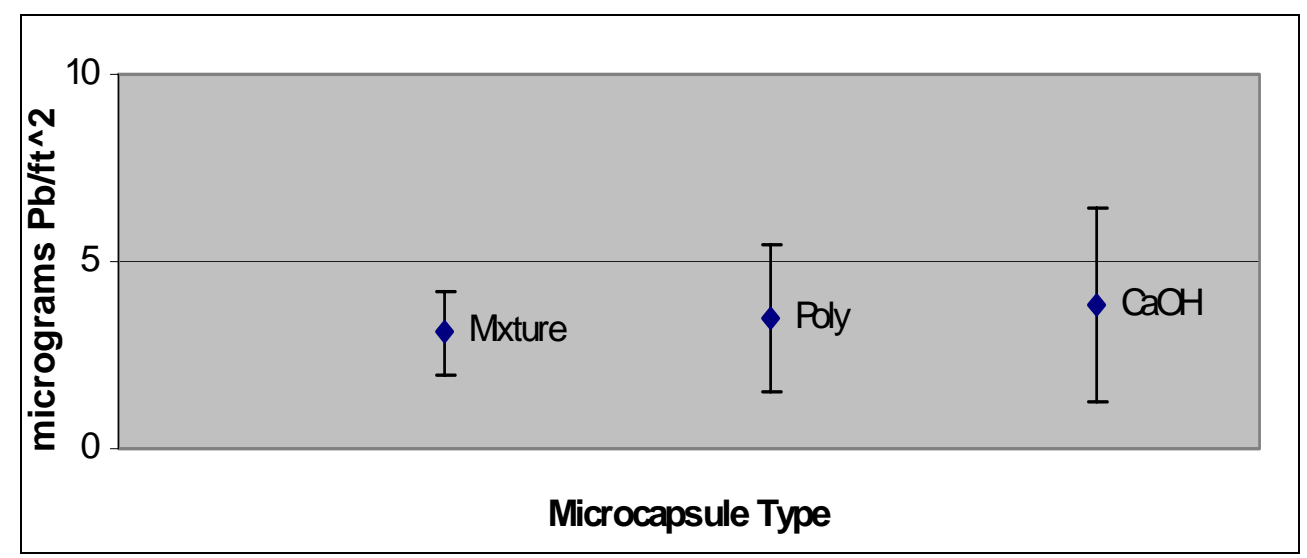

Figure 10. ASTM E1728 results with microcapsules applied using a brush with expanded scale to show comparison of various microcapsule-laden coatings. 


\section{Conclusions from Laboratory Testing}

The four types of lead suppression microcapsules were thoroughly tested over a number of different time intervals. All of the types of microcapsules used provided some protection against lead dust. The most effective type of microcapsules when used alone was $\mathrm{Ca}(\mathrm{OH})$ type. These microcapsules proved to be very effective when applied both with a Baker Film Applicator and with a brush. The polybutene microcapsules were also effective in preventing lead dust. Although they did not perform as strongly as the $\mathrm{Ca}(\mathrm{OH})$ microcapsules, they were still superior to the controls. The overall best lead suppression results were realized by mixing the $\mathrm{Ca}(\mathrm{OH})$ and polybutene microcapsules in a 50/50 ratio. This mixture of microcapsules was effective at any time interval and always outperformed the controls.

\section{Advantages and Limitations of the Technology}

Overcoating with self-healing coatings is an emerging technology. Although microcapsules are not available in large commercial quantities at this time, manufacturing technology is available to produce these microcapsules.

This technology is limited to application onto existing coatings that meet overcoating criteria have been properly prepared for overcoating. Also, this technology has been tested only for overcoating LBP on wood. 


\section{Demonstration Design}

\section{Performance Objectives}

The primary performance objectives are listed in Table 8.

Table 8. Performance objectives.

\begin{tabular}{|l|l|l|l|}
\hline $\begin{array}{l}\text { Type of Performance } \\
\text { Objective }\end{array}$ & $\begin{array}{l}\text { Primary Performance } \\
\text { Criterion }\end{array}$ & $\begin{array}{l}\text { Expected Perform- } \\
\text { ance (Metric) }\end{array}$ & $\begin{array}{l}\text { Performance } \\
\text { Objective Met? }\end{array}$ \\
\hline Quantitative & $\begin{array}{l}\text { Long-term abatement } \\
\text { of lead hazard }\end{array}$ & $\begin{array}{l}<50 \mu \mathrm{g} / \mathrm{ft}^{2} \mathrm{~Pb} \text { (wipe } \\
\text { test) }\end{array}$ & Unknown \\
\hline Quantitative & $\begin{array}{l}\text { Short-term abatement } \\
\text { of lead hazard }\end{array}$ & $\begin{array}{l}<50 \mu \mathrm{g} / \mathrm{ft}^{2} \mathrm{~Pb} \text { (wipe } \\
\text { test) }\end{array}$ & Yes \\
\hline Qualitative & $\begin{array}{l}\text { Application equivalent } \\
\text { to conventional latex } \\
\text { paint }\end{array}$ & Ease of application & Yes \\
\hline
\end{tabular}

\section{Selection of Test Site/Facility}

The former Fort Ord at Marina, CA, was selected for the demonstration because of the widespread presence of LBP on most buildings. Marina, CA, represents a relatively wet marine climate with high levels of incident ultraviolet (UV) radiation. The site is a challenging exterior test environment. The former Fort Ord is administered by the Fort Ord Reuse Authority.

\section{Test Facility History/Characteristics}

Interior and exterior applications were performed on Building T2862, $12^{\text {th }}$ Street. The existing exterior paint was in generally good condition with only slight peeling and cracking (Figure 11). The adhesion of the existing exterior paint was tested in accordance with ASTM D 3359 Standard Test Methods for Measuring Adhesion by Tape Test (ASTM 2002b) (Figure 12). Adhesion was found to be acceptable for recoating (2A to $5 \mathrm{~A})$. The interior application was performed on wood support columns and windows. 


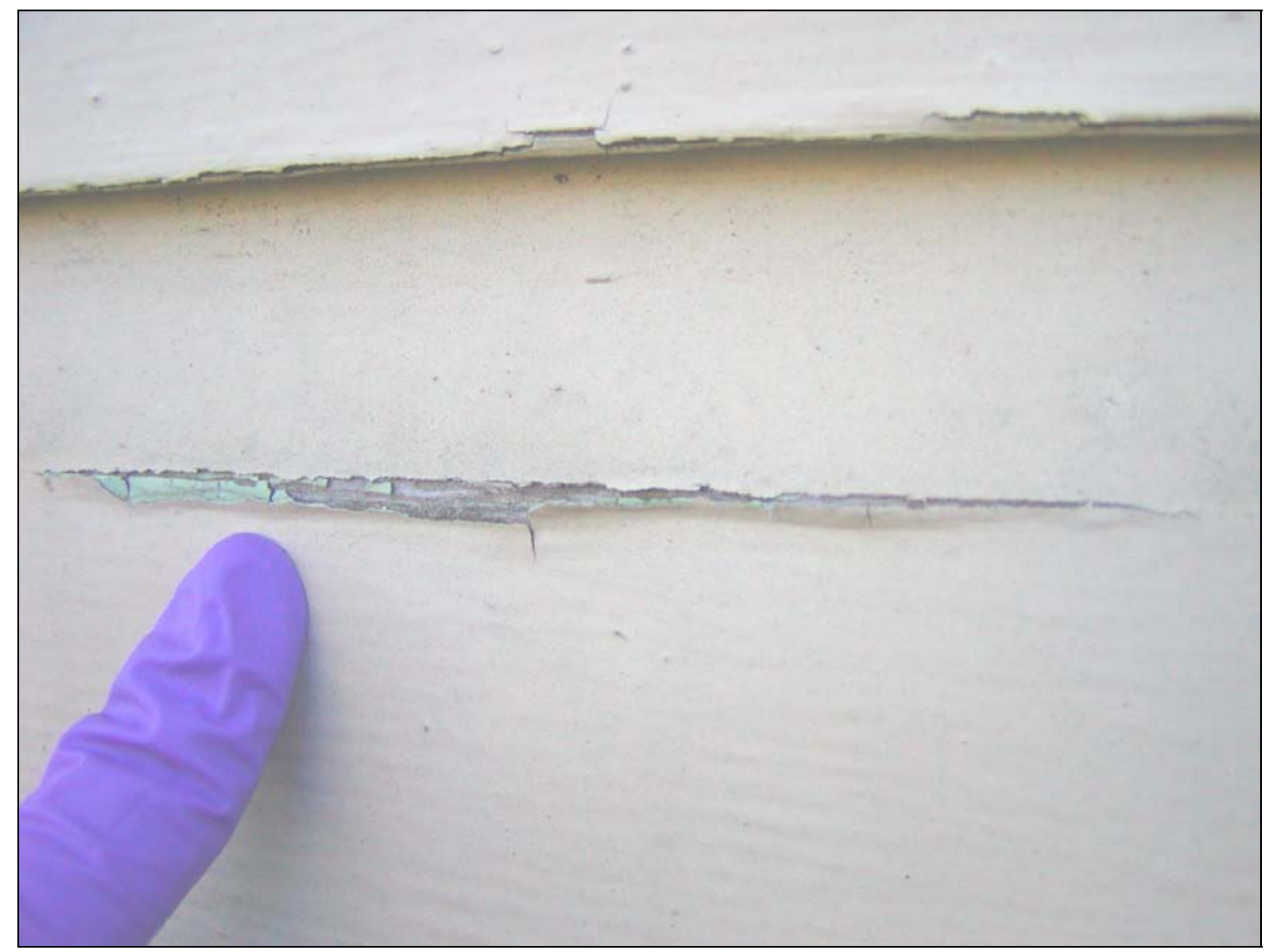

Figure 11. Preexisting condition of painted exterior wood siding.

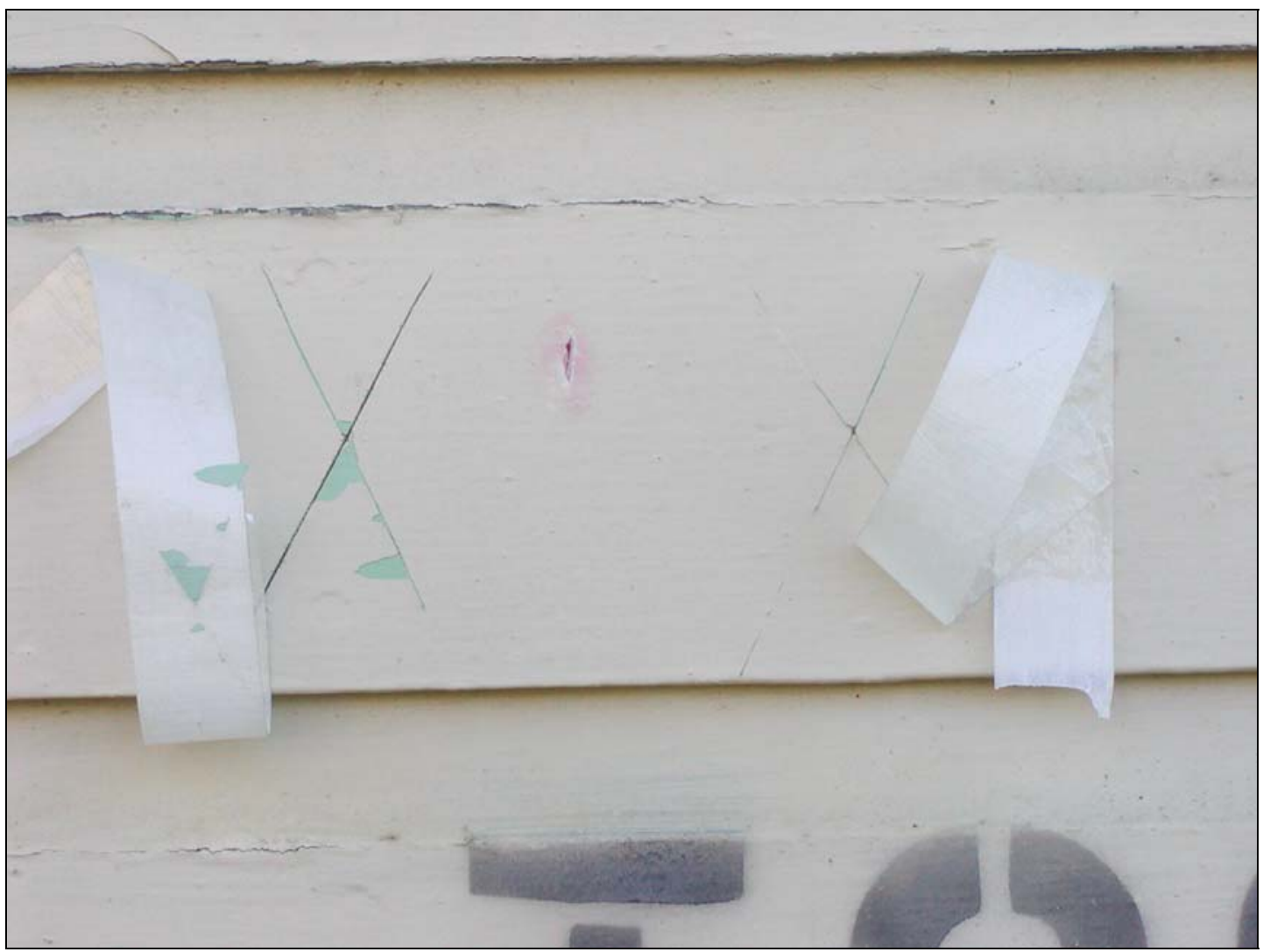

Figure 12. Crosscut adhesion testing of old exterior paint. 
LeadCheck Swabs were used to qualitatively verify the presence of lead in the existing paint (Figure 13). The swabs are a colorimetric indicator with a detection limit of 2,000 ppm lead. Confirmatory quantitative lead analyses were performed by a certified lead laboratory and are presented in Table 9.

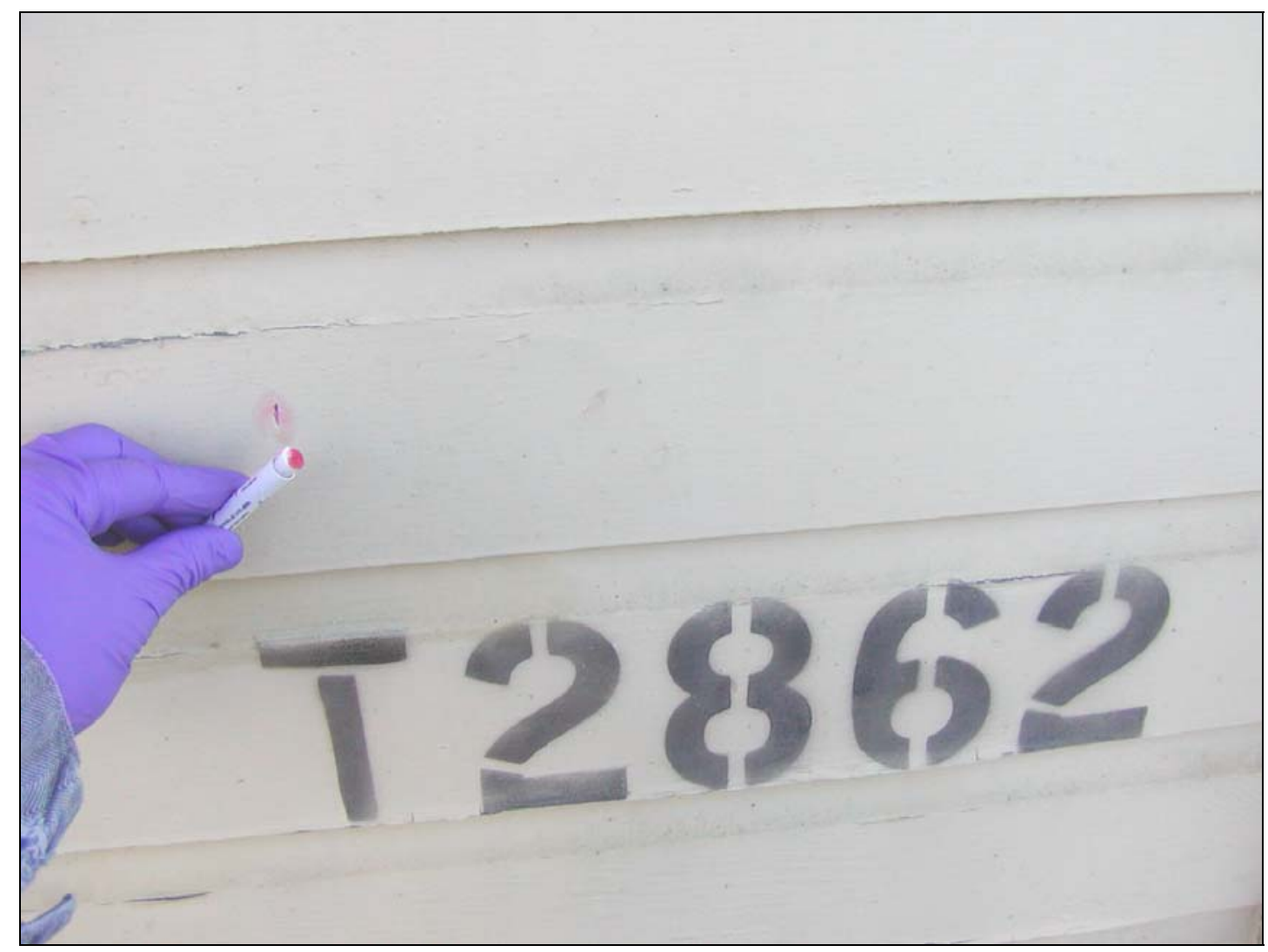

Figure 13. Verification of lead in old exterior paint.

Table 9. Lead in existing coatings.

\begin{tabular}{|l|l|l|}
\hline Test Location & Result by weight (percent) & Reporting Limit (percent) \\
\hline Exterior Siding & 16 & 0.0050 \\
\hline Interior Columns & 0.019 & 0.0050 \\
\hline Interior Windows & 0.13 & 0.0050 \\
\hline
\end{tabular}

\section{Physical Setup and Operation}

Manufactured microcapsules were added to commercially available interior and exterior latex coatings. Laboratory research has indicated that 30 percent by weight capsules in the dried film is sufficient to ensure self-healing properties provided the material is applied at the recommended spreading rate. A volume-solids ratio 
would be preferable to a weight-solids ratio. However, additional research is needed to determine an appropriate volume-solids ratio. A 50/50 weight ratio of microcapsules containing polybutene and calcium hydroxide was used. The microcapsules were 63 to 150 microns in diameter with a urea formaldehyde shell. Table 10 shows the paint and microcapsule materials used and their quantities for the interior and exterior applications.

Table 10. Interiorlexterior self-healing paints.

\begin{tabular}{|l|l|l|l|}
\hline Paint Product & $\begin{array}{l}\text { Paint Solids } \\
\text { (Ib/gallon paint) }\end{array}$ & $\begin{array}{l}\mathrm{Ca}(\mathrm{OH})_{2} \\
\text { Microcapsules } \\
\text { (Ib/gallon paint) }\end{array}$ & $\begin{array}{l}\text { Polybutene } \\
\text { Microcapsules } \\
\text { (Ib/gallon paint) }\end{array}$ \\
\hline $\begin{array}{l}\text { Sherwin-Williams A-100® } \\
\text { Exterior Satin Latex }\end{array}$ & 4.54 & 0.97 & 0.97 \\
\hline
\end{tabular}

The exterior test surface was wooden siding. The $100-\mathrm{ft}^{2}$ test area was cleaned to remove loose chalk using a solution of sodium sesquicarbonate and sodium metasilicate in water. The cleaner was applied and the surface was scrubbed using a nonwoven abrasive pad. The surface was thoroughly rinsed with clean water and then allowed to dry (Figure 14).

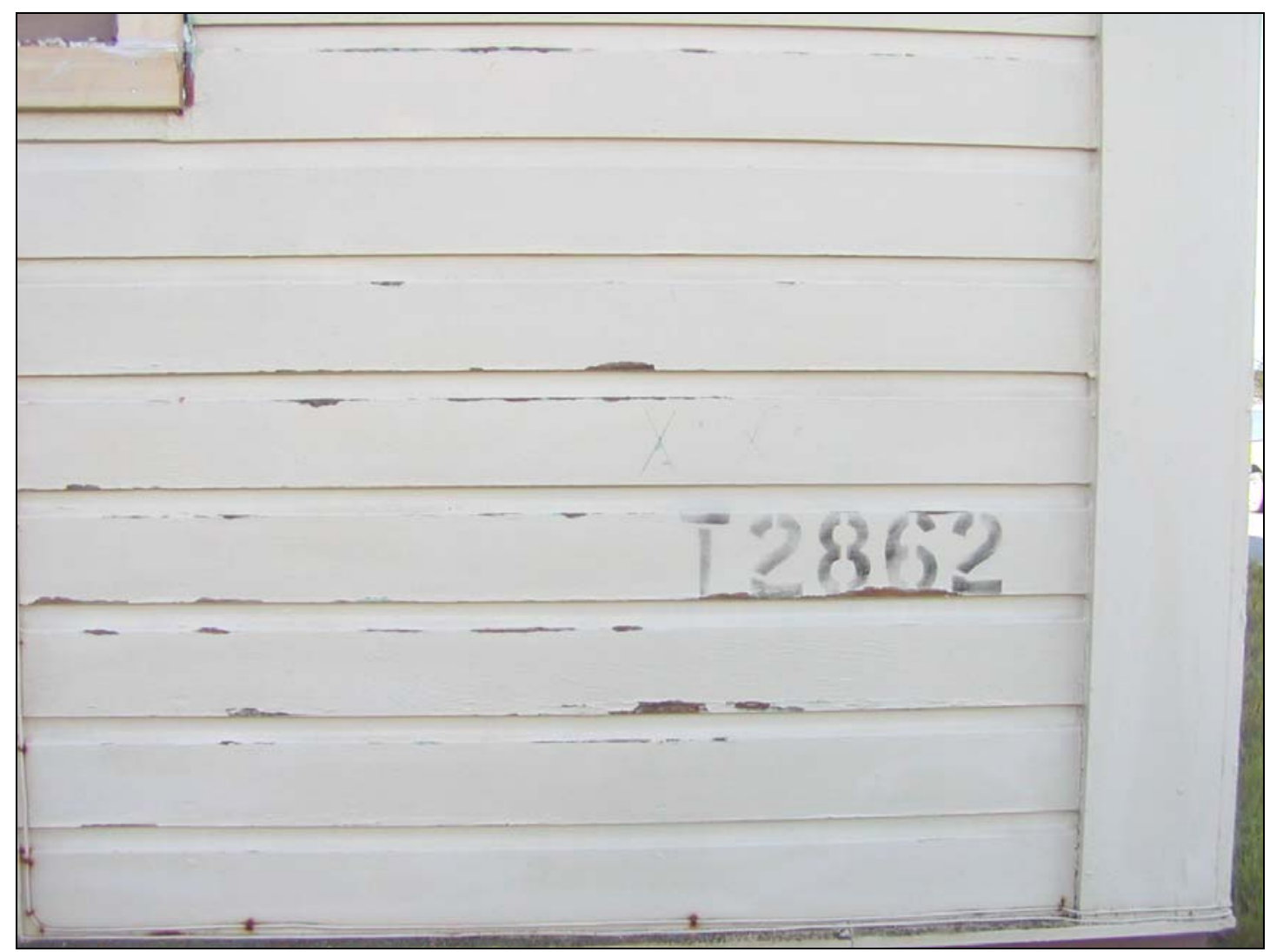

Figure 14. Cleaned exterior wood siding ready for painting. 
Microcapsules (Figure 15) were weighed and gradually hand stirred into the liquid paint until uniformly dispersed. The self-healing coating was then applied by brush to $50 \mathrm{ft}^{2}$ of the exterior test area (Figure 16). The other $50 \mathrm{ft}^{2}$ was coated with the same paint (Sherwin-Williams A-100) without microcapsules. The coated areas were allowed to dry overnight and were then painted with a second coat of latex paint (A-100) without microcapsules.

The process was repeated for the interior test area except that the test area was not washed prior to coating (Figure 17).

The application of the self-healing coating was conducted 4 and 5 March 2003. Coating performance was evaluated 6 March 2003.

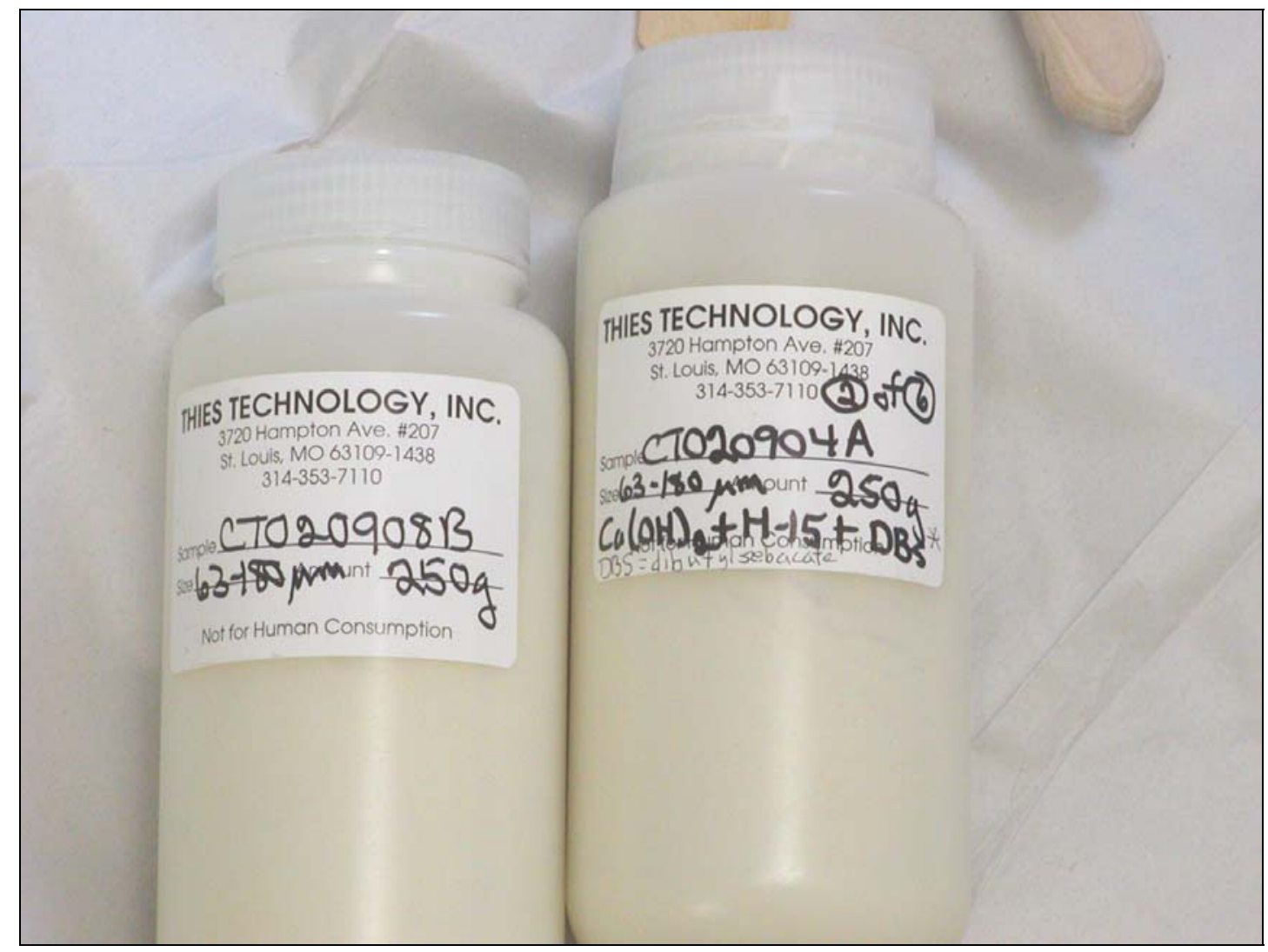

Figure 15. Polybutene and calcium hydroxide microcapsules. 


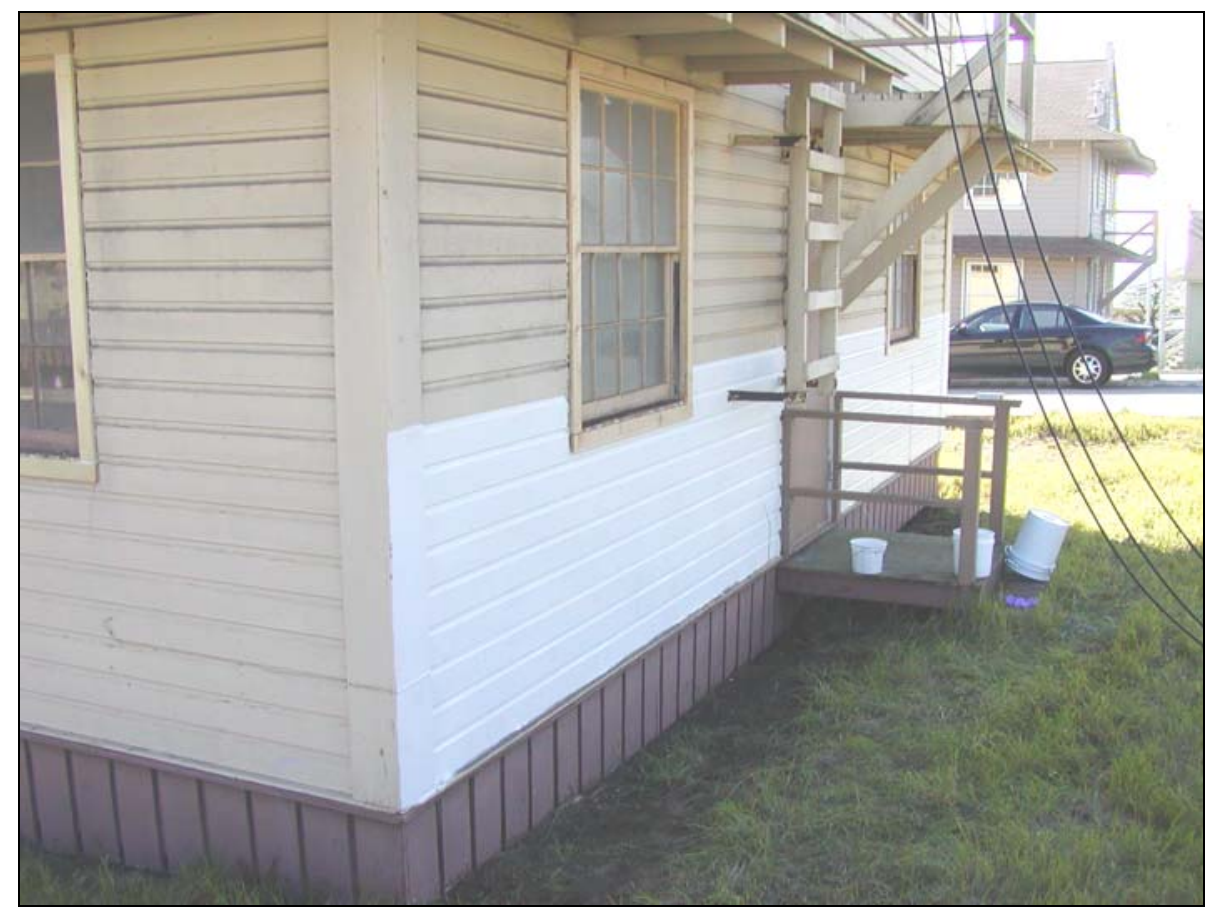

Figure 16. Exterior application of self-healing coating.

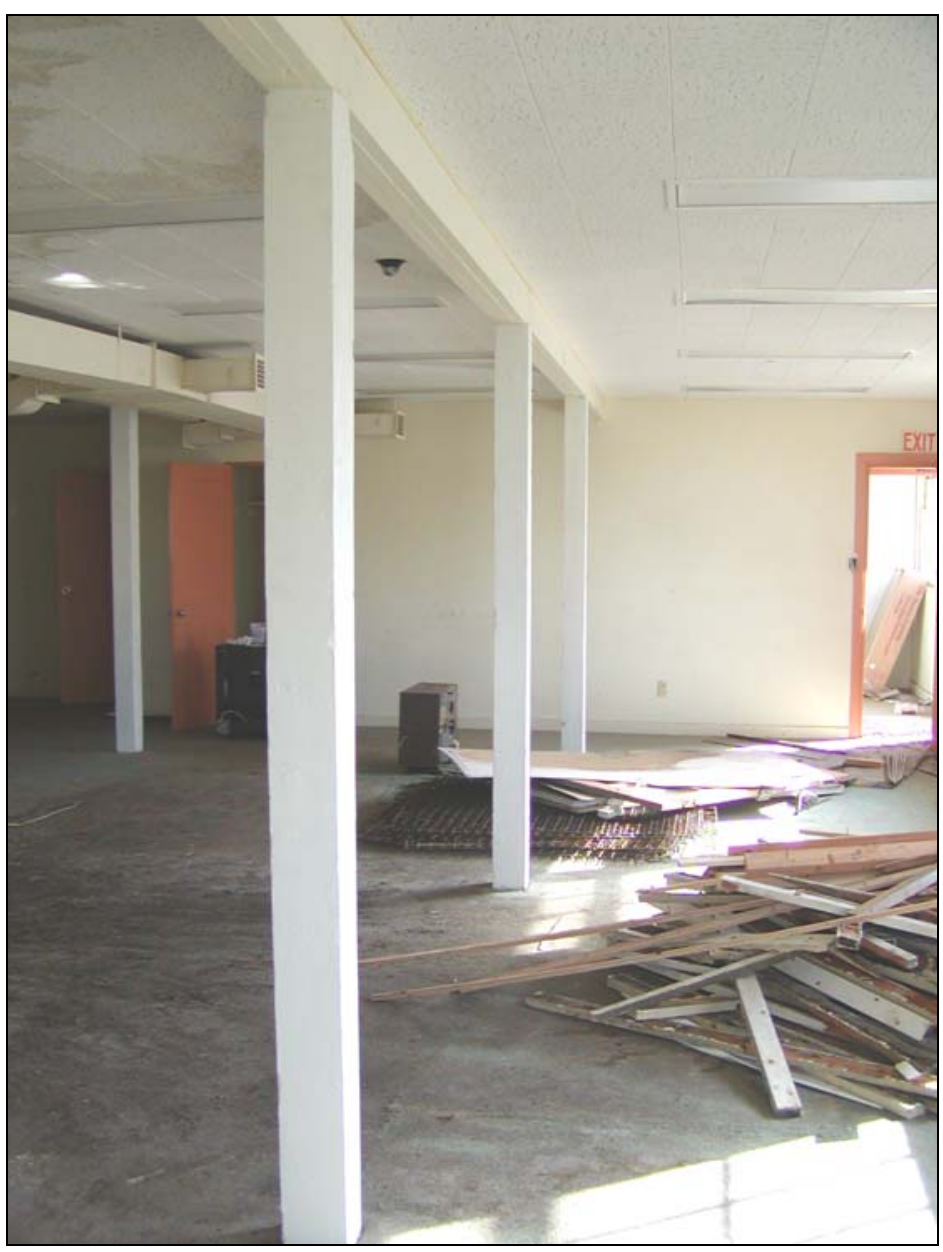

Figure 17. Interior application of self-healing coatings. 
The control and self-healing coating materials used for the demonstration are described in Tables 11 and 12 respectively.

Table 11. Description of acrylic latex coating.

\begin{tabular}{|l|l|l|}
\hline Paint Vehicle Type & Solids (percent) \\
\hline \multirow{2}{*}{ Latex acrylic } & Weight & Volume \\
\cline { 2 - 4 } & 45 & 33 \\
\hline
\end{tabular}

Table 12. Description of self-healing technology.

\begin{tabular}{|l|l|l|l|l|l|l|l|l|}
\hline $\begin{array}{l}\text { Paint } \\
\text { Vehicle } \\
\text { Type }\end{array}$ & \multicolumn{2}{l}{$\begin{array}{l}\text { Base Paint Solids } \\
\text { (percent) }\end{array}$} & \multicolumn{2}{l|l}{$\begin{array}{l}\text { Polybutene Cap- } \\
\text { sule Solids (per- } \\
\text { cent) }\end{array}$} & \multicolumn{2}{l|}{$\begin{array}{l}\text { CaOH Capsule } \\
\text { Solids (percent) }\end{array}$} & \multicolumn{2}{l|}{$\begin{array}{l}\text { Self-Healing Total } \\
\text { Solids (percent) }\end{array}$} \\
\hline $\begin{array}{l}\text { Latex } \\
\text { acrylic }\end{array}$ & weight & volume & weight & volume & weight & volume & weight & volume \\
\cline { 2 - 9 } & 26 & 23 & 18 & 21 & 21 & 69 & 67 \\
\hline
\end{tabular}

Approximately 0.25 gal of self-healing paint was applied to $50 \mathrm{ft}^{2}$ of exterior siding. The calculated dry film thickness of self-healing coating for the exterior application was 5.2 mils. Approximately 0.16 gal of latex paint was used to coat the $50-\mathrm{ft}^{2}$ control area. The calculated dry film thickness of the latex control coating is 1.65 mils. Approximately 0.23 gal of latex paint was used to recoat the exterior control and self-healing coatings. The calculated dry film thickness of the exterior latex topcoat was 1.25 mils.

About 0.20 gal of self-healing paint was used to paint the $50-\mathrm{ft}^{2}$ interior area. The calculated dry film thickness for the interior self-healing paint application was 4.15 mils. Approximately 0.15 gal of latex paint was used to coat the $50-\mathrm{ft}^{2}$ control area. The calculated dry film thickness of the latex control coating was 1.45 mils. Approximately 0.23 gal of latex paint was used to recoat the interior control and selfhealing coatings. The calculated dry film thickness of the interior latex topcoat was 1.2 mils.

The recommended spreading rate based on laboratory investigations was 8 mil wet film thickness or about 5.2 mils dry based on the solids contents of the self-healing coating used for the field application. Within experimental error the recommended application rate was achieved for both interior and exterior test areas.

\section{Sampling/Monitoring Procedures}

Test coatings were applied to surfaces known to be coated with LBP. 
The self-healing and control coatings were subjected to intentional damage (scribing) followed by wipe tests to evaluate the short-term self-healing properties of the coating. Wipe tests were performed on 4 - by 4 -in. test areas each with eight 4 -in.long scribes through the coating to the substrate (Figure 18). Wipe test samples were taken 20 minutes after the scribes were cut. Individual wipe test kits were used for each test area.

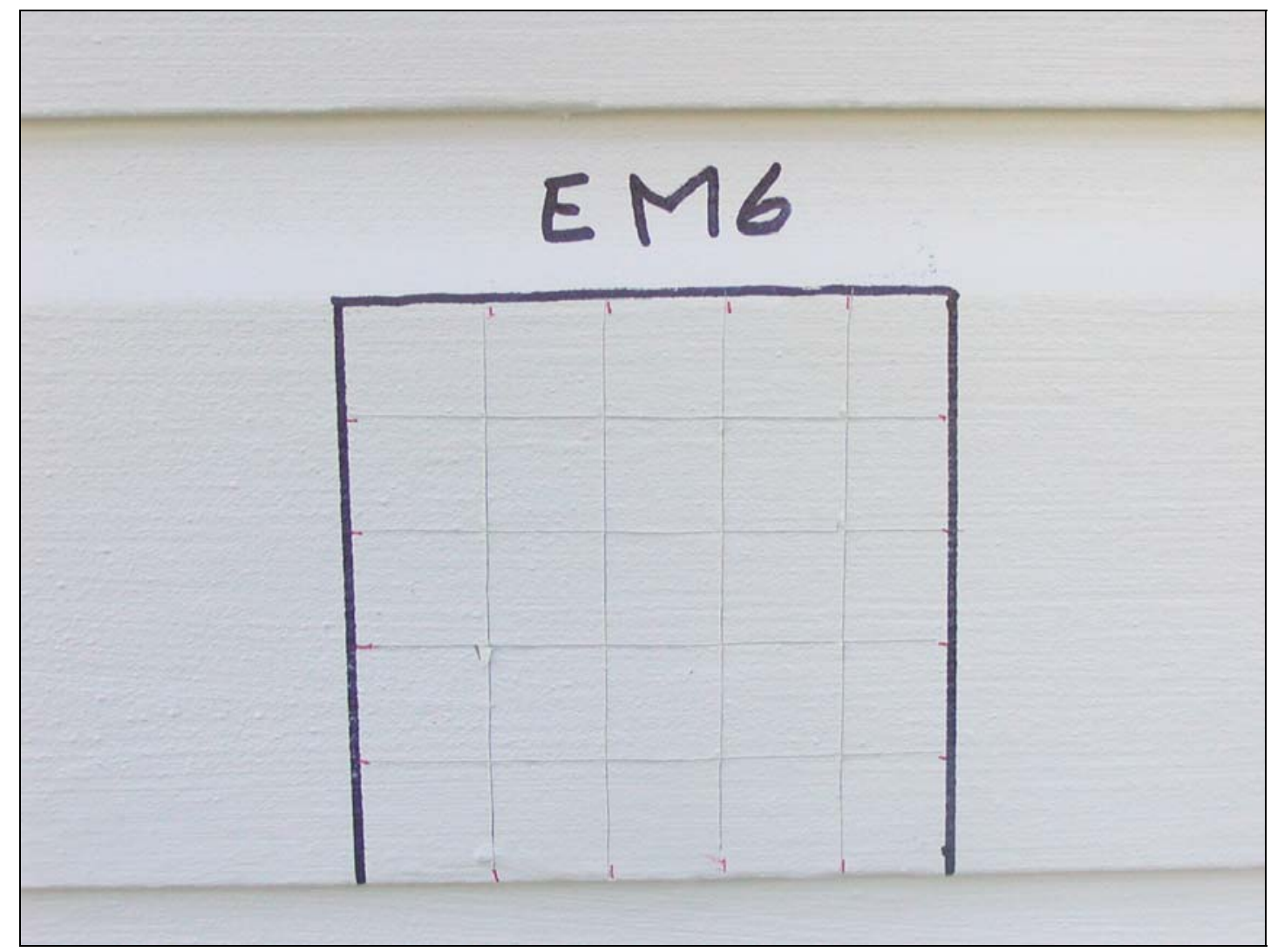

Figure 18. Scribed test area for wipe testing of self-healing coating.

\section{Analytical Procedures}

Wipe tests were performed in accordance with ASTM E1728-95 Standard Practice for Field Collection of Settled Dust Samples using Wipe Sampling Methods for Lead Determination by Atomic Spectrometry Techniques. Wipe and paint chip samples were prepared for total lead analysis in accordance with EPA 600/R-93/200M-P (Total Metals in Paint Chips, Sonication) (Luk et al. 1993) and analyzed in accordance with EPA 6010B (Unductively Coupled Plasma - Atomic Emission Spectrometry Method for Determination of Metals) (EPA 1986). 


\section{Performance Assessment}

\section{Performance Data}

The short-term performance data are presented in Table 13. Table 14 summarizes the same data.

Table 13. Short-term performance data.

\begin{tabular}{|c|c|c|}
\hline Sample Identification & Sample Location & Result ( $\left.\mu \mathrm{g} / \mathrm{ft}^{2} \mathrm{~Pb}\right)$ \\
\hline IC1 & Interior column 1 & ND \\
\hline IC2 & Interior column 1 & ND \\
\hline IC3 & Interior column 2 & 126 \\
\hline IC4 & Interior column 2 & 56 \\
\hline IC5 & Interior column 3 & ND \\
\hline IC6 & Interior column 3 & ND \\
\hline IM1 & Interior column 4 & ND \\
\hline IM2 & Interior column 4 & ND \\
\hline IM3 & Interior column 5 & ND \\
\hline IM4 & Interior column 5 & ND \\
\hline IM5 & Interior column 6 & ND \\
\hline IM6 & Interior column 6 & ND \\
\hline IM7 & Interior window & ND \\
\hline IM8 & Interior window & ND \\
\hline EC1 & Exterior siding west corner & ND \\
\hline EC2 & Exterior siding west corner & ND \\
\hline EC3 & Exterior siding west corner & ND \\
\hline EC4 & Exterior siding west & 1,980 \\
\hline EC5 & Exterior siding west & 2,340 \\
\hline EC6 & Exterior siding west & 3,150 \\
\hline EM1 & Exterior siding east corner & ND \\
\hline EM2 & Exterior siding east corner & 117 \\
\hline EM3 & Exterior siding east corner & 441 \\
\hline EM4 & Exterior siding east & ND \\
\hline EM5 & Exterior siding east & 153 \\
\hline EM6 & Exterior siding east & ND \\
\hline
\end{tabular}

Notes: $\mathrm{C}=$ control samples

$M=$ samples of self-healing coatings containing microcapsules

$\mathrm{ND}=$ non-detectable at the reporting limit of $45 \mu \mathrm{g} / \mathrm{ft}^{2} \mathrm{~Pb}$ 


\section{Performance Criteria}

The primary performance criteria are listed in Table 14.

Table 14. Performance criteria.

\begin{tabular}{|l|l|l|l|}
\hline $\begin{array}{l}\text { Type of } \\
\text { Performance } \\
\text { Criterion }\end{array}$ & $\begin{array}{l}\text { Primary } \\
\text { Performance } \\
\text { Criterion }\end{array}$ & Performance Criterion & Actual Performance \\
\hline Quantitative & $\begin{array}{l}\text { Abatement of lead } \\
\text { hazard for 10 years }\end{array}$ & $<50 \mu \mathrm{g} / \mathrm{ft}^{2} \mathrm{~Pb}$ (wipe test) & Unknown \\
\cline { 2 - 4 } & $\begin{array}{l}\text { Abatement of lead } \\
\text { hazard on intention- } \\
\text { ally damaged paint }\end{array}$ & $<50 \mu \mathrm{g} / \mathrm{ft}^{2} \mathrm{~Pb}$ (wipe test) & $\begin{array}{l}\text { Average } 45 \mu \mathrm{g} / \mathrm{ft}^{2} \mathrm{~Pb} \text { interior* } \\
\left.\text { (Interior control } 60 \mu \mathrm{g} / \mathrm{ft}^{2} \mathrm{~Pb}\right)\end{array}$ \\
\hline Qualitative & $\begin{array}{l}\text { Application equivalent } \\
\text { to latex paints }\end{array}$ & $\begin{array}{l}\text { Ease of application by brush } 140 \mu \mathrm{g} / \mathrm{ft}^{2} \mathrm{~Pb} \text { exterior } \\
\text { - no runs, sags, curtains, or } \\
\text { other application defects at } \\
\left.\text { (Exterior control } 1,300 \mu \mathrm{g} / \mathrm{ft}^{2} \mathrm{~Pb}\right)\end{array}$ & $\begin{array}{l}\text { No runs, sags, curtains, or other } \\
\text { application defects at specified } \\
\text { application rate. }\end{array}$ \\
\hline
\end{tabular}

*Detection limit $45 \mu \mathrm{g} / \mathrm{ft}^{2} \mathrm{~Pb}$ - no lead was detected in any of the interior self-healing samples.

\section{Data Assessment}

Mixing was readily accomplished by gradually adding the microcapsules to the paint while stirring. Mixing time was about 5 minutes. The consistency of the selfhealing paint was very thick, but the material could still be poured.

There were no application-related defects, and appearance was acceptable when the paint was applied by brush. However, there was increased drag on the brush, and subsequent greater degree of effort was needed to apply the self-healing coating compared with the same paint without microcapsules. Application could be improved by using a purpose formulated latex base with lower solids content.

All of the interior post-scribe wipe tests on self-healing coatings returned lead concentrations below the performance criterion of $50 \mu \mathrm{g} / \mathrm{ft}^{2}$. However, two of six controls had detectable lead levels.

Three of the six exterior wipe tests in the control area had detectable lead levels, all of which exceeded the performance criterion of $50 \mu \mathrm{g} / \mathrm{ft}^{2}$. Three of the six exterior wipe tests on the self-healing coating also had detectable lead levels, all of which were above the performance criterion of $50 \mu \mathrm{g} / \mathrm{ft}^{2}$. 
The average wipe test lead level for interior surfaces coated with self-healing coating was $45 \mu \mathrm{g} / \mathrm{ft}^{2}$ lead, or the same as the method detection limit. Tests on interior control surfaces were only slightly higher with an average of $60 \mu \mathrm{g} / \mathrm{ft}^{2} \mathrm{lead}$. The tests on interior surfaces show a 25 percent improvement in coating performance.

The average wipe test lead level for exterior surfaces coated with self-healing coating was $140 \mu \mathrm{g} / \mathrm{ft}^{2}$ lead. Tests on exterior control surfaces were significantly higher with an average of $1,300 \mu \mathrm{g} / \mathrm{ft}^{2}$ lead. The tests on exterior surfaces demonstrate the short-term efficacy of the self-healing coating, i.e., an 89 percent improvement in coating performance.

\section{Technology Comparison}

Self-healing coatings should be durable on interior surfaces for at least 20 years. However, exterior applications are not as forgiving. Coatings last longer in exterior environments if the substrate is dimensionally stable. Such is the case with concrete and stucco building surfaces. Wood, on the other hand, absorbs water and goes through fairly significant dimensional changes. These changes coupled with the degradation of the coating itself usually mean that coatings on exterior wood last less than 10 years. It is likely that self-healing coatings will significantly extend the maintenance cycle on exterior wood surfaces beyond the generally accepted maximum life of plain latex paint overcoatings of 7 to 10 years.

Another inherent feature of thick film elastomeric latex coatings is their relatively low water permeability compared to conventional architectural coatings. This property can be beneficial because elastomeric coating will reduce water migration to the substrate, which in turn enhances long-term coating performance. However, this same feature can be problematic. Lower permeability also means that water can build up underneath the coating. This typically results in premature failure of the coating. The phenomenon occurs when water enters the building envelope because of poor construction such as unsealed wall penetrations, unprotected roof parapets, or poorly caulked windows. Once inside of the wall, water will attempt to pass through the coating when the ambient temperature is cooler than the temperature of the wall. Elastomeric coatings pass water vapor at a lower rate. When the driving force exceeds the ability of the coating to pass water vapor, liquid water will form under the coating, creating blisters. Irreversible film deformation may occur as well as substrate degradation. Ultimately the coating loses adhesion and must be repaired or replaced. 


\section{Cost Performance Assessment}

\section{Cost of Self-Healing Overcoatings}

The cost analysis for applying self-healing coatings to $1,000 \mathrm{sq} f t$ of LBP on a wood surface is shown in Table 15. The cost analysis for applying latex paint without self-healing microcapsules is shown in Table 16.

Table 15. Costs for applying self-healing coatings (per 1,000 sq ft.)

\begin{tabular}{|c|c|c|c|c|c|}
\hline Activity & Time/Cost & Activity & Time/Cost & Activity & Time/Cost \\
\hline $\begin{array}{l}\text { Surface Prepara- } \\
\text { tion }\end{array}$ & & $\begin{array}{l}\text { Mix and Apply } \\
\text { Self-Healing Coat- } \\
\text { ing }\end{array}$ & & $\begin{array}{l}\text { Mix and Apply } \\
\text { Topcoat }\end{array}$ & \\
\hline Rate (painter) $\$ / \mathrm{hr}$ & 40 & Rate (painter) $\$ / \mathrm{hr}$ & 40 & Rate (painter) $\$ / \mathrm{hr}$ & 40 \\
\hline Hours & 2 & Hours & 15 & Hours & 15 \\
\hline Labor subtotal & $\$ 80$ & & $\$ 600$ & & $\$ 600$ \\
\hline \multirow[t]{2}{*}{$\begin{array}{l}\text { Consumable } \\
\text { Materials }\end{array}$} & & $\begin{array}{l}5 \text { gal. latex paint } \\
@ \$ 20 / g a l\end{array}$ & $\$ 100$ & $\begin{array}{l}2.5 \text { gal. latex paint } \\
@ \$ 20 / \mathrm{gal}\end{array}$ & $\$ 50$ \\
\hline & & $\begin{array}{l}9.7 \text { lb microcap- } \\
\text { sules } @ \$ 16 / l b\end{array}$ & $\$ 155$ & & \\
\hline Materials subtotal & & & $\$ 255$ & & $\$ 50$ \\
\hline $\begin{array}{l}\text { Overhead on direct } \\
\text { labor @ } 90 \%\end{array}$ & $\$ 56$ & & $\$ 420$ & & $\$ 420$ \\
\hline Category total & $\$ 136$ & & $\$ 1,275$ & & $\$ 1,070$ \\
\hline $\begin{array}{l}\text { General \& Admin. } \\
\text { Overhead @30\% }\end{array}$ & $\$ 41$ & & $\$ 383$ & & $\$ 321$ \\
\hline Subtotal & & & & & $\$ 3,225$ \\
\hline Profit @15\% & & & & & $\$ 484$ \\
\hline TOTAL & & & & & $\$ 3,709$ \\
\hline $\begin{array}{l}\text { Unit Area Cost } \\
\text { (UAC) }\end{array}$ & & & & & $\$ 3.71$ \\
\hline
\end{tabular}


Table 16. Costs for applying latex paint (per 1,000 sq ft.)

\begin{tabular}{|c|c|c|c|c|c|}
\hline Activity & Time/Cost & Activity & Time/Cost & Activity & Time/Cost \\
\hline Surface Preparation & & $\begin{array}{l}\text { Mix and Apply Self- } \\
\text { Healing Coating }\end{array}$ & & $\begin{array}{l}\text { Mix and Apply } \\
\text { Topcoat }\end{array}$ & \\
\hline Rate (painter) $\$ / \mathrm{hr}$ & 40 & Rate (painter) $\$ / \mathrm{hr}$ & 40 & Rate (painter) \$/hr & 40 \\
\hline Hours & 2 & Hours & 15 & Hours & 15 \\
\hline Labor subtotal & $\$ 80$ & & $\$ 600$ & & $\$ 600$ \\
\hline $\begin{array}{l}\text { Consumable } \\
\text { Materials }\end{array}$ & & $\begin{array}{l}5 \text { gal. latex paint @ } \\
\$ 20 / \text { gal }\end{array}$ & $\$ 100$ & $\begin{array}{l}2.5 \text { gal. latex paint } \\
@ \$ 20 / g a l\end{array}$ & $\$ 50$ \\
\hline & & $\begin{array}{l}9.7 \text { lb microcap- } \\
\text { sules @ } \$ 16 / \mathrm{lb}\end{array}$ & $\$ 0$ & & \\
\hline Materials subtotal & & & $\$ 100$ & & $\$ 50$ \\
\hline $\begin{array}{l}\text { Overhead on direct } \\
\text { labor @ } 70 \%\end{array}$ & $\$ 56$ & & $\$ 420$ & & $\$ 420$ \\
\hline Category total & $\$ 136$ & & $\$ 1,120$ & & $\$ 1,070$ \\
\hline $\begin{array}{l}\text { General \& Admin. } \\
\text { Overhead @ } 30 \%\end{array}$ & $\$ 41$ & & $\$ 336$ & & $\$ 321$ \\
\hline Subtotal & & & & & $\$ 3,024$ \\
\hline Profit @15\% & & & & & $\$ 454$ \\
\hline TOTAL & & & & & $\$ 3,477$ \\
\hline $\begin{array}{l}\text { Unit Area Cost } \\
\text { (UAC) }\end{array}$ & & & & & $\$ 3.48$ \\
\hline
\end{tabular}

\section{Cost Analysis}

Material costs for self-healing coatings are based on a projected mean cost for microcapsules of $\$ 16 / \mathrm{lb}$ and a projected latex paint price of $\$ 20 /$ gal. Based on the results of this demonstration, it is projected that $0.97 \mathrm{lb}$ of both polybutene microcapsules and $0.97 \mathrm{lb}$ of $\mathrm{CaOH}$ microcapsules should be used per gallon of paint. To cover $1,000 \mathrm{sq} \mathrm{ft}$ of wood surface, 5 gal of paint must be mixed with $9.7 \mathrm{lb}$ of microcapsules, and 2.5 gal of latex paint must be used for topcoat. 


\section{Cost Comparison}

The unit area cost of self-healing coatings is $\$ 3.71 / \mathrm{sq} \mathrm{ft}$, and the unit area cost of plain latex coatings is $\$ 3.48 / \mathrm{sq} \mathrm{ft}$. The only difference between the use of latex paint overcoatings and self-healing overcoatings is the projected cost of the microcapsules at $\$ 0.23$ per sq $\mathrm{ft}$. The addition of the microcapsules results in an increase of 6.2 percent to the cost of overcoating. Note that in the laboratory testing, the selfhealing overcoatings showed a 95 percent improvement in coating performance over the controls, while in the field demonstration, they resulted in 25 to 89 percent improvement in coating performance, i.e., lead dust reduction. Thus, the life cycle extension of the overcoatings is projected to range from 25 to 95 percent (with a mean value of 60 percent) by the incorporation of the self-healing microcapsules.

The generally accepted maximum life of plain latex paint overcoatings is 7 to 10 years on exterior surfaces due to degradation by the ultraviolet light component of sunlight and only 4 years on interior surfaces due to wear and tear from the hands of children. Based on the reduction in lead dust, self-healing coatings have the potential to provide a projected increase in the life of the overcoating by 4.2 to 6 years for exterior surfaces and by 2.4 years for interior surfaces. For plain latex overcoatings, the unit area costs per year of coating life range from $\$ 0.34 / \mathrm{sq} \mathrm{ft} /$ year to $\$ 0.50 / \mathrm{sq} \mathrm{ft} / \mathrm{year}$ for exterior coatings and $\$ 0.87 / \mathrm{sq} \mathrm{ft} / \mathrm{year}$ for interior coatings. For self-healing overcoatings, the potential unit area costs per year range from $\$ 0.23 / \mathrm{sq}$ $\mathrm{ft} /$ year to $\$ 0.33 / \mathrm{sq} \mathrm{ft} /$ year for exterior coatings, and $\$ 0.58 / \mathrm{sq} \mathrm{ft} /$ year for interior coatings. In either case, the cost benefit from using self-healing coatings for both exterior and interior surfaces, is projected to be 33 percent over the 11.2 to 16 years for exterior coatings, or over 6.4 years for interior coatings in child-accessible areas, compared with plain latex overcoatings. Self-healing coatings should be used only for overcoating LBP on exterior surfaces or interior surfaces in high wear-and-tear areas. 


\section{Summary}

\section{Implementation Costs}

Self-healing coatings are an attractive alternative to latex paint overcoatings based on estimated costs. Based on the results of this technology demonstration, the unit area cost of self-healing coatings was shown to be is $\$ 3.71 / \mathrm{sq} \mathrm{ft}$, and the unit area cost of plain latex coatings was $\$ 3.48 / \mathrm{sq} \mathrm{ft}$. However, the material costs for selfhealing coatings are projected, and actual costs could be significantly higher or lower depending on the size of the market.

Although the addition of the microcapsules results in an increase of 6.2 percent to the cost of overcoating, the self-healing overcoatings showed a 95 percent reduction in lead dust over the controls in the laboratory. In the field demonstration, they resulted in 25 to 89 percent reduction in lead dust performance, with a mean lead reduction of 60 percent. On the basis of lead dust reduction, the service life of the coating is extended by 60 percent. Since the generally accepted maximum life of plain latex paint overcoatings is 7 to 10 years on exterior surfaces and 4 years on interior surfaces due to wear and tear at the hands of children, the coating lives are extended by 4.2 to 6 years for exterior coatings and 2.4 years for interior coatings. For plain latex overcoatings, the unit area costs per year of coating life range from $\$$ $0.34 / \mathrm{sq} \mathrm{ft} /$ year to $\$ 0.50 / \mathrm{sq} \mathrm{ft} /$ year for exterior coatings and $\$ 0.87 / \mathrm{sq} \mathrm{ft} /$ year for interior coatings. For self-healing overcoatings, the potential unit area costs per year range from $\$ 0.23 / \mathrm{sq} \mathrm{ft} /$ year to $\$ 0.33 / \mathrm{sq} \mathrm{ft} /$ year for exterior coatings, and $\$ 0.58 / \mathrm{sq}$ $\mathrm{ft} /$ year for interior coatings. When used on both exterior and interior surfaces, the self-healing overcoatings are projected to result in a life cycle cost savings of 33 percent over the 11.2 to 16 years for exterior coatings, or over 6.4 years for interior coatings, compared with plain latex overcoatings.

\section{Performance Observations}

For the interior and exterior tests, there were no application-related defects, and appearance was acceptable when the paint was applied by brush. However, there was a significant amount of drag on the brush, and subsequently a greater degree of 
effort was needed to apply the self-healing coating compared with the same paint without microcapsules.

Three of the six exterior wipe tests in the control area had detectable lead levels, all of which exceeded the performance criterion of $50 \mu \mathrm{g} / \mathrm{ft}^{2}$. Three of the six exterior wipe tests on the self-healing coating also had detectable lead levels, all above the performance criterion of $50 \mu \mathrm{g} / \mathrm{ft}^{2}$.

The average wipe test lead level for exterior surfaces coated with self-healing coating was $140 \mu \mathrm{g} / \mathrm{ft}^{2}$ lead. Tests on exterior control surfaces were significantly higher with an average of $1,300 \mu \mathrm{g} / \mathrm{ft}^{2}$ lead. The tests on exterior surfaces demonstrates the short-term efficacy of the self-healing coating, showing an 89 percent reduction in lead dust, compared to the plain latex coating.

All of the interior post-scribe wipe tests on self-healing coatings returned lead concentrations below the performance criterion of $50 \mu \mathrm{g} / \mathrm{ft}^{2}$. However, two of six controls had detectable lead levels while none of the wipe tests on the self-healing coating had detectable lead. Lead wipe test results on interior control surfaces (plain latex coatings) averaged $60 \mu \mathrm{g} / \mathrm{ft}^{2}$ lead. The average wipe test lead level for interior surfaces coated with self-healing coating was $45 \mu \mathrm{g} / \mathrm{ft}^{2}$ lead, or the same as the method detection limit, which meets the performance criteria of $<50 \mu \mathrm{g} / \mathrm{ft}^{2}$ lead. The lead wipe tests on interior surfaces showed a 25 percent reduction in lead dust over the plain latex coating. Self-healing coatings should be used only for overcoating LBP on exterior surfaces or interior surfaces in high wear-and-tear areas. 


\section{References}

Army Regulation [AR] 420-70, Buildings and Structures, (Headquarters, Department of the Army [HQDA], Washington, DC, 11 November 1997).

ASTM E1728, Standard Practice for Collection of Settled Dust Samples Using Wipe Sampling Methods for Subsequent Lead Determination (ASTM International, West Conshohocken, PA, 2002a).

ASTM D3359, Standard Testing Method for Measuring Adhesion by Tape (ASTM International, West Conshohocken, PA, 2002b).

ASTM E2252, Standard Practice for the Selection of Lead Hazard Reduction Methods for Identified Risks in Residential Housing or Child Occupied Facilities (ASTM International, West Conshohocken, PA, 2003).

Bartlett, D. J., "High-Build Latex Coatings for Protecting and Decorating Concrete and Related Building Surfaces," Journal of Protective Coating and Linings, September 2001.

Davis-Bacon Wage Determinations (on the Government Printing Office web site, GPO Access) http://www.access.gpo.gov/davisbacon/

Defense Information Systems Agency, Acquisition Deskbook - Independent Government Cost Estimates, http://disa.dtic.mil/D4/igce98.html

Luk, K. K., P. M. Grohse, L. L. Hodson, D. A. Binstock, and C. C. VanHise, Standard Operating Procedure for the Field Analysis of Lead in Paint, Bulk Dust, and Soil by Ultrasonic, Acid Digestion and Colorimetric Measurement, DPO 600/R-93/200 (EPA, Research Triangle Institute, Research Triangle Park, NC, 1993).

National Institute for Occupational Safety and Health, "Lead by Flame AAS: Method 7082," Issue $2,4^{\text {th }}$ ed., 15 August 1994.

SSPC: The Society for Protective Coatings, "Paint Application," Steel Structures Painting Manual, vol 1, Chapter 5.1, Paint Application, 3 $3^{\text {rd }}$ ed. (1993).

Unified Facilities Guide Specifications, Section 13281A, Lead Hazard Control Activities, April 2000.

U.S. Army Center for Public Works, Installation Lead Hazard Management, Public Works Technical Bulletin 420-70-2, Alexandra, VA, 20 February 1997.

U.S. Environmental Protection Agency, Inductively Coupled Plasma - Atomic Emission Spectrometry, Test Method 6010B (Office of Solid Waste and Emergency Response, 1986). 
U. S. Department of Housing and Urban Development, Guidelines for the Evaluation and Control of Lead-Based Paint Hazards in Housing, Washington, DC (June 1995). 


\section{Points of Contact}

\begin{tabular}{|c|c|c|c|}
\hline Name & Organization & Phone/Fax/E-mail & $\begin{array}{l}\text { Role in Pro- } \\
\text { ject }\end{array}$ \\
\hline $\begin{array}{l}\text { Dr. Ashok } \\
\text { Kumar }\end{array}$ & $\begin{array}{l}\text { ERDC/CERL } \\
\text { P. O. Box } 9005 \\
\text { Champaign, IL 61826-9005 }\end{array}$ & $\begin{array}{l}\text { Tel: 217-373-7235 } \\
\text { Fax: 217-373-7222 } \\
\text { E-mail: a-kumar@cecer.army.mil }\end{array}$ & $\begin{array}{l}\text { Principal In- } \\
\text { vestigator }\end{array}$ \\
\hline $\begin{array}{l}\text { Dr. L. D. } \\
\text { Stephenson }\end{array}$ & $\begin{array}{l}\text { ERDC/CERL } \\
\text { P. O. Box } 9005 \\
\text { Champaign, IL 61826-9005 }\end{array}$ & $\begin{array}{l}\text { Tel: 217-373-6758 } \\
\text { Fax: 217-373-7222 } \\
\text { E-mail: I-stephenson@cecer.army.mil }\end{array}$ & $\begin{array}{l}\text { Contracting } \\
\text { Officer's } \\
\text { Technical } \\
\text { Representa- } \\
\text { tive }\end{array}$ \\
\hline Tim Race & $\begin{array}{l}\text { Corrosion Control Consultants and Labs } \\
135 \text { Addison Ave., Suite } 108 \\
\text { Elmhurst, IL } 60126\end{array}$ & $\begin{array}{l}\text { Tel: 630-834-3811 } \\
\text { Fax: 630-834-3812 } \\
\text { E-mail: trace@ccclabs.com }\end{array}$ & $\begin{array}{l}\text { Principal } \\
\text { Consultant }\end{array}$ \\
\hline Stan Cook & $\begin{array}{l}\text { Fort Ord Reuse Authority } \\
10012^{\text {th }} \text { Street, Building } 2880 \\
\text { Marina, CA } 93933\end{array}$ & $\begin{array}{l}\text { Tel: 831-883-3672 } \\
\text { E-mail: stan@fora.org }\end{array}$ & $\begin{array}{l}\text { Facility } \\
\text { Contact }\end{array}$ \\
\hline
\end{tabular}




\title{
Acronyms
}

\author{
AR Army Regulation \\ ASTM American Society for Testing and Materials \\ CFR Code of Federal Regulations \\ DISA Defense Information Systems Agency \\ EPA U.S. Environmental Protection Agency \\ ICP-AES Inductively Coupled Plasma - Atomic Emission Spectroscopy \\ LBP lead-based paint \\ POM Presidio of Monterey \\ PPM parts per million \\ TCLP Toxic Characteristic Leaching Procedure \\ UAC unit area cost \\ UFGS Unified Facilities Guide Specification \\ UV ultraviolet
}




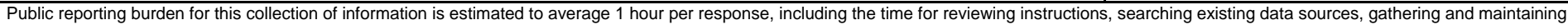

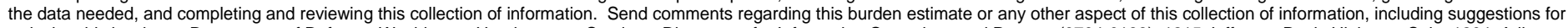

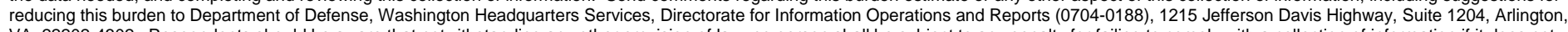

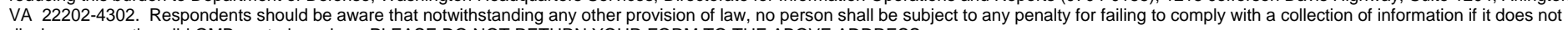
display a currently valid OMB control number. PLEASE DO NOT RETURN YOUR FORM TO THE ABOVE ADDRESS.

\begin{tabular}{|l|l|l|l}
\hline 1. REPORT DATE (DD-MM-YYYY) & 2. REPORT TYPE & 3. DATES COVERED (From - To) \\
7-2003 & & Final
\end{tabular}

\section{TITLE AND SUBTITLE}

Final

Technology Demonstration of Self-Healing Coatings for In-Place Management of Lead-

Based Paint Hazards

\section{5a. CONTRACT NUMBER}

5b. GRANT NUMBER

5c. PROGRAM ELEMENT NUMBER 063728A

\section{AUTHOR(S)}

L. D. Stephenson and Ashok Kumar 5d. PROJECT NUMBER

5e. TASK NUMBER

5f. WORK UNIT NUMBER

CF-M B101

8. PERFORMING ORGANIZATION

REPORT NUMBER

ERDC/CERL TR-03-29

U.S. Army Engineer Research and Development Center (ERDC)

Construction Engineering Research Laboratory (CERL)

PO Box 9005

Champaign, IL 61826-9005

\section{SPONSORING I MONITORING AGENCY NAME(S) AND ADDRESS(ES)}

Headquarters, Department of the Army

Attn: DAIM-FDF

600 Army Pentagon

Washington, DC 2031-0600

\section{DISTRIBUTION I AVAILABILITY STATEMENT}

Approved for public release; distribution is unlimited.

\section{SUPPLEMENTARY NOTES}

Copies are available from the National Technical Information Service, 5285 Port Royal Road, Springfield, VA 22161.

\section{ABSTRACT}

Microcapsules on the order of 50-150 microns in size have been developed that can contain and release a small quantity of selfrepairing compound in liquid form when they are broken. These microcapsules are mixed in commercially available latex paints and used to overcoat lead-based paint. Should the overcoating become damaged, the microcapsules break open and release liquid coating repair and lead dust suppression compounds. In effect, the coating becomes self-healing when damaged. The self-healing coatings were tested in the laboratory and demonstrated on a wooden building at the former Fort Ord, CA. In both cases, when the self-healing coatings were applied to lead based paint, cut, and wipe tested, significant reductions in lead dust were realized compared with the results of applying the same test procedure to plain latex paint overcoatings.

\section{SUBJECT TERMS}

lead-based paint (LBP), hazardous waste, coatings, paint, self-healing coatings, wooden buildings, Fort Ord, CA

\begin{tabular}{|c|c|c|c|c|c|}
\hline \multicolumn{3}{|c|}{ 16. SECURITY CLASSIFICATION OF: } & \multirow{2}{*}{$\begin{array}{l}\text { 17. LIMITATION } \\
\text { OF ABSTRACT } \\
\text { SAR }\end{array}$} & \multirow{2}{*}{$\begin{array}{l}\text { 18. NUMBER } \\
\text { OF PAGES } \\
47\end{array}$} & 19a. NAME OF RESPONSIBLE \\
\hline $\begin{array}{l}\text { a. REPORT } \\
\text { Unclassified }\end{array}$ & $\begin{array}{l}\text { b. ABSTRACT } \\
\text { Unclassified }\end{array}$ & $\begin{array}{l}\text { c. THIS PAGE } \\
\text { Unclassified }\end{array}$ & & & $\begin{array}{c}\text { 19b. TELEPHONE NUMBER (in- } \\
\text { clude area code) } \\
217 / 352-6511\end{array}$ \\
\hline
\end{tabular}

